\title{
Serum amyloid P inhibits granulocyte adhesion
}

\author{
Anu S Maharjan ${ }^{1,2}$, David Roife ${ }^{1}$, Derrick Brazill ${ }^{3}$ and Richard H Gomer ${ }^{2 *}$
}

\begin{abstract}
Background: The extravasation of granulocytes (such as neutrophils) at a site of inflammation is a key aspect of the innate immune system. Signals from the site of inflammation upregulate granulocyte adhesion to the endothelium to initiate extravasation, and also enhance granulocyte adhesion to extracellular matrix proteins to facilitate granulocyte movement through the inflamed tissue. During the resolution of inflammation, other signals inhibit granulocyte adhesion to slow and ultimately stop granulocyte influx into the tissue. In a variety of inflammatory diseases such as acute respiratory distress syndrome, an excess infiltration of granulocytes into a tissue causes undesired collateral damage, and being able to reduce granulocyte adhesion and influx could reduce this damage.

Results: We found that serum amyloid P (SAP), a constitutive protein component of the blood, inhibits granulocyte spreading and granulocyte adhesion to extracellular matrix components. This indicates that in addition to granulocyte adhesion inhibitors that are secreted during the resolution of inflammation, a granulocyte adhesion inhibitor is present at all times in the blood. Although SAP affects adhesion, it does not affect the granulocyte adhesion molecules CD11b, CD62L, CD18, or CD44. SAP also has no effect on the production of hydrogen peroxide by resting or stimulated granulocytes, or $\mathrm{N}$-formyl-methionine-leucine-phenylalanine (fMLP)-induced granulocyte migration. In mice treated with intratracheal bleomycin to induce granulocyte accumulation in the lungs, SAP injections reduced the number of granulocytes in the lungs.
\end{abstract}

Conclusions: We found that SAP, a constitutive component of blood, is a granulocyte adhesion inhibitor. We hypothesize that SAP allows granulocytes to sense whether they are in the blood or in a tissue.

Keywords: Serum amyloid P, Neutrophil, Adhesion, Acute respiratory distress syndrome, ARDS, ALI

\section{Background}

Infections or injuries to tissues such as the lungs cause the damaged cells to recruit immune cells, including granulocytes and monocytes, to the injury site $[1,2]$. The transmigration of granulocytes such as neutrophils to the site of injury or infection requires the interaction of neutrophils with endothelial cells and extracellular matrices $[1,3,4]$. In blood vessels, neutrophils are generally quiescent, but after an injury or infection, neutrophils begin to tether and roll on the blood vessel using the selectin family of adhesion molecules such as CD62L, CD62P, and P-selectin glycoprotein ligand-1 (PSGL-1) [5-7]. These adhesion molecules interact with endothelial cell adhesion molecules such as E-selectin, P-selectin, and PSGL-1 [5-7]. Activated endothelial cells also interact with neutrophil glycoproteins such as CD44

\footnotetext{
* Correspondence: rgomer@tamu.edu

²Department of Biology, MS-3474, Texas A\&M University, College Station, TX 77843-3474, USA

Full list of author information is available at the end of the article
}

and CD43 through E-selectin to slow neutrophil rolling $[5,8]$. CD44 interacts with E-selectin and causes the redistribution of PSGL-1 or L-selectin on rolling neutrophils, which then promotes the tethering of neutrophils and slows downthe rolling velocity [5]. The slow neutrophil rolling allows neutrophils to sense signals such as interleukin (IL)-8, tumor necrosis factor (TNF) $\alpha$, granulocyte macrophage colony-stimulating factor (GM-CSF), or $N$-formylmethionine-leucine-phenylalanine (fMLP) from damaged cells or infection [5,9-13], and activate integrin adhesion molecules such as CD11b and CD18 [6,7,9,14-16]. IL-8 is a neutrophil chemoattractant that can induce neutrophil degranulation and enhance neutrophil production of reactive oxygen species $[9,16]$. TNF $\alpha$ and GM-CSF increase neutrophil adherence, release of reactive oxygen species, and phagocytosis [10-13]. fMLP resembles bacterial waste products, and activates neutrophil chemotaxis [17-20].

The upregulation of the adhesion molecules CD11b and CD18 let neutrophils interact with endothelial ligands such as intercellular adhesion molecule 1 (ICAM-1), 
which causes neutrophils to firmly adhere to the endothelium [7] and move through the blood vessel into an injured site [15]. Integrin molecules such as CD11b and CD18 can also bind to extracellular matrix components such as fibronectin, fibrinogen, laminin, and collagen, and this binding aids in the movement of neutrophils through extracellular matrices $[1,3,4]$. Other integrin adhesion molecules such as CD61 facilitate leukocyte migration, but little is known about their roles in neutrophil migration. Once activated neutrophils are at injured sites, they can release reactive oxygen species and proteases, and then engulf bacteria and debris by phagocytosis [21,22].

In the normal resolution of wound healing, activated granulocytes such as neutrophils undergo programmed cell death, which prevents the release of reactive oxygen species from the granulocytes, thereby preventing any cell damage in the surrounding tissue [23]. Since activated granulocytes can damage surrounding cells, cytokines such as IL-4 and IL-10 inhibit excessive recruitment of granulocytes into the site of injury [24-27]. IL-4 and IL-10 inhibit the production of IL- 8 and the release of TNF $\alpha$ and IL-1 $\beta$, which in turn limits granulocyte accumulation and activation [24,25,27]. Lipid mediators such as lipoxin $\mathrm{A}_{4}\left(\mathrm{LXA}_{4}\right)$ and lipoxin $\mathrm{B}_{4}\left(\mathrm{LXB}_{4}\right)$ inhibit neutrophil recruitment by reducing neutrophil adhesion to endothelial cells and vascular permeability [28,29]. Other lipid mediators including D-series and E-series resolvins and protectins also inhibit transendothelial migration of neutrophils [30,31].

Secreted pentraxin proteins such as pentraxin-3 (PTX3) and C-reactive protein (CRP) also limit neutrophil recruitment to a site of injury [32-37]. PTX3 is a pentraxin that is produced and released by monocytes, dendritic cells, endothelial cells, and smooth muscle cells in response to inflammatory signals such as IL-1 $\beta$, TNF $\alpha$, or Toll-like receptor (TLR) agonists [38]. CRP is a pentraxin secreted into the blood by the liver as an acute phase protein in humans, and inhibits neutrophil adhesion and chemotaxis on activated endothelial cells [33,36]. Neutrop hils recognize the pentraxin family of proteins through Fc $\gamma$ receptors [39,40]. Neutrophils express high levels of Fc $\gamma$ RII (CD32) and FcyRIII (CD16), and express low or undetectable levels of FcyRI (CD64) [41,42]. These receptors bind to the Fc portion of IgG immunoglobulins [43] or pentraxin proteins such as PTX3, CRP, and serum amyloid P (SAP), and help in the opsonization and phagocytosis of bacteria or debris [44-47]. Serum amyloid P is a pentraxin that is constitutively secreted into the blood by the liver [44]. The circulating SAP levels are approximately $30 \mu \mathrm{g} / \mathrm{ml}$ in humans [48], and approximately $15 \mu \mathrm{g} / \mathrm{ml}$ in C57BL/6 mice [49]. SAP effectively inhibits the differentiation of monocytes to fibrocytes [50,51] through FcyRI and FcR $\gamma$ [51]. In vivo, injections of SAP significantly reduce bleomycin-induced pulmonary fibrosis in mice and rats [52]. Although it has been reported that SAP elicits antifibrotic activity by stimulating IL-10 [53], a recent study has shown that highly purified SAP does not stimulate IL-10 production [54].

Little is known about SAP's interaction with granulocytes, which have $\mathrm{Fc} \gamma$ receptors. Activated granulocytes release reactive oxygen species such as hydrogen peroxide and superoxide anions through activation of NADPH oxidase [55] to kill microbes such as bacteria. However, excessive release of these cytotoxic products can further damage an injured tissue. SAP appears to decrease neutrophil oxygen metabolism [56], but SAP has no effect on the production of hydrogen peroxide by neutrophils stimulated by digitonin, mistletoe lectin, or fMLP [57]. IL- 8 is a chemoattractant, and SAP has been reported to bind IL- 8 [58]. In the presence of IL-8, SAP decreases neutrophil binding to fibronectin coated plates [58]. However, in the absence of IL-8, SAP acts as a neutrophil chemoattractant and increases neutrophil adhesion [58]. SAP increases the percentage of neutrophils expressing adhesion molecules such as CD11b and CD18 and the fibronectin receptor $\alpha 5 \beta 1$ [58]. In flow chambers, SAP inhibits the binding of human neutrophils to TNF $\alpha$-stimulated human umbilical vein endothelial cells [59]. Since granulocytes can recognize SAP through Fc receptors, and the reports of the regulation of neutrophil adhesion by SAP seem inconsistent, we examined the effect of SAP on granulocyte adhesion and recruitment to sites of inflammation.

\section{Materials and methods}

\section{Isolating peripheral blood mononuclear cells (PBMCs) or} granulocytes

Blood was collected from healthy adult volunteers with specific approval from the Institutional Review Boards of Rice University and Texas A\&M University. Written consent was received and all samples were deidentified before analysis. PBMCs were isolated and incubated in RPMI serum-free medium (SFM) as described previously [60]. Granulocytes were isolated from blood using Lympholyte-poly (Cedarlane Laboratories, Hornby, Canada) following the manufacturer's directions and resuspended in RPMI-1640 (Sigma) or 2\% bovine serum albumin (BSA) (Fraction V, A3059, Sigma) in RPMI1640. To check the purity of the granulocytes, $100 \mu \mathrm{l}$ of the isolated granulocytes were analyzed by flow cytometry (Accuri Cytometers, Ann Arbor, MI, USA) using the combination of forward scatter (correlates to cell size) and side scatter (correlates to cell granularity). Isolated granulocytes were larger and more granular than other cells. As an additional check of granulocyte purity, $200 \mu \mathrm{l}$ of $0.5 \times 10^{6}$ cells $/ \mathrm{ml}$ granulocytes in $2 \%$ BSARPMI was aliquoted into a well of an eight-well glass chamber slides (Lab-Tek, Nalge Nunc International, 
Naperville, IL, USA) for $1 \mathrm{~h}$ at $37^{\circ} \mathrm{C}$. After incubation, $150 \mu \mathrm{l}$ of media was removed and the slide was spun at $400 \mathrm{~g}$ for 5 minutes using a cytospin centrifuge (Shandon, Runcorn, UK). The cells were then fixed with $200 \mu \mathrm{l}$ of $2 \%$ paraformaldehyde (PFA) in phosphate-buffered saline (PBS) for 15 minutes at room temperature. After the PFA was removed, $400 \mu \mathrm{l}$ of ice-cold methanol was added to the wells for $1 \mathrm{~h}$ at $4^{\circ} \mathrm{C}$ to permeabilize the cells. After gently removing the methanol, $400 \mu \mathrm{l}$ of PBS was added to the wells for 10 minutes at room temperature and then gently pipetted out from the corner of the well. This was repeated twice. The slide was then mounted with a 4',6diamidino-2-phenylindole (DAPI)-containing mounting media (Vectashield, Vector Laboratories). Images of the cells were captured on an Axioplan2 microscope (Zeiss) with a CoolSNAP HQ digital camera (Photometrics, Tucson, AZ, USA) and Metamorph software (Molecular Devices, Dowington, PA, USA).

\section{Production of human SAP or murine SAP}

Human SAP (hSAP) was from Calbiochem (CalbiochemEMD Chemicals, Darmstadt, Germany). Commercial human SAP was buffer exchanged with $20 \mathrm{mM}$ sodium phosphate buffer as described previously [60]. Human SAP or murine SAP (mSAP) were also prepared from commercially available human serum (Gemini, West Sacramento, CA, USA) or murine serum (Gemini) using calcium-dependent binding to phosphoethanolamineconjugated agarose as described previously [52]. Commercial or purified SAP was stored at $1 \mathrm{mg} / \mathrm{ml}$ in $20 \mathrm{mM}$ sodium phosphate buffer, $\mathrm{pH} 7.4$ at $-20^{\circ} \mathrm{C}$.

\section{Granulocyte spreading assay with cell debris}

PBMCs at $1 \times 10^{6}$ cells $/ \mathrm{ml}$ in SFM were lysed with a Dounce homogenizer and a drill-driven Teflon pestle (Thomas Scientific, Swedesboro, NJ, USA) at 300 RPM for 60 strokes to make cell debris. Then, $100 \mu \mathrm{l}$ of PBMCs at $0.5 \times 10^{6}$ cells $/ \mathrm{ml}$ were incubated in flat bottom 96-well tissue culture plates (BD, Franklin Lakes, NJ, USA) in the presence or absence of $100 \mu \mathrm{l}$ of undiluted debris at $37^{\circ} \mathrm{C}$. After 7 days, the supernatants were clarified by centrifugation at $10,000 \mathrm{~g}$ for $10 \mathrm{mi}$ nutes. Supernatants were collected into Eppendorf tubes and flash frozen with liquid nitrogen, and stored at $-80^{\circ}$ $\mathrm{C}$ until further use. A total of $100 \mu \mathrm{l}$ of $5 \times 10^{5}$ cells $/ \mathrm{ml}$ granulocytes were incubated in $20 \mu \mathrm{g} / \mathrm{ml} \mathrm{SAP}$ in RPMI, $25 \%$ PBMC supernatant in RPMI, a mix of $25 \%$ PBMC supernatant and $20 \mu \mathrm{g} / \mathrm{ml} \mathrm{SAP}$ in RPMI, or in RPMI. After $1 \mathrm{~h}$, fields of granulocytes were photographed using a phase-contrast microscope with a $20 \times$ objective. Granulocytes and spread granulocytes were then counted.

\section{Granulocyte adhesion}

Wells of flat bottom 96-well tissue culture plates (BD) were precoated with $50 \mu \mathrm{l}$ of $20 \mu \mathrm{g} / \mathrm{ml}$ bovine plasma fibronectin (Sigma) in PBS or $20 \mu \mathrm{g} / \mathrm{ml}$ cellular human foreskin fibroblast fibronectin (Sigma) in PBS for $1 \mathrm{~h}$ at $37^{\circ} \mathrm{C}$. After removing the fibronectin, the wells were washed three times with $200 \mu \mathrm{l}$ of PBS and then blocked with $200 \mu \mathrm{l}$ of $2 \%$ BSA-PBS for $2 \mathrm{~h}$ at room temperature. The wells were then washed three times with $200 \mu \mathrm{l}$ of PBS and once with $200 \mu \mathrm{l}$ of $2 \%$ BSA-RPMI before adding granulocytes. A total of $500 \mu \mathrm{l}$ of granulocytes at $1 \times 10^{6}$ cells $/ \mathrm{ml}$ in $2 \%$ BSA-RPMI were incubated in an Eppendorf tube (preincubated with 2\% BSA-RPMI for $2 \mathrm{~h}$ at $37^{\circ} \mathrm{C}$ ), and SAP (or an equal volume of buffer) was added to a final concentration of $30 \mu \mathrm{g} / \mathrm{ml}$ for 30 minutes at $37^{\circ} \mathrm{C}$. A total of $100 \mu \mathrm{l}$ of $1 \times 10^{6} \mathrm{cells} / \mathrm{ml}$ granulocytes was then incubated in the well of a 96-well plate for 10 minutes at $37^{\circ} \mathrm{C}$ to allow granulocytes to settle. Then, $1 \mu \mathrm{l}$ of $10 \mu \mathrm{g} / \mathrm{ml}$ recombinant human TNF $\alpha$ (Peprotech, NJ, USA) in 2\% BSA-RPMI was then added to the well and gently mixed by stirring with the pipette tip. After a 30 -minute incubation with TNF $\alpha$ at $37^{\circ} \mathrm{C}$, non-adherent granulocytes were removed and the wells were washed three times by pipetting in and then removing $100 \mu \mathrm{l}$ of $37^{\circ} \mathrm{C}$ PBS. The plate was then air dried, stained with methylene blue and eosin (Richard-Allan Scientific, Kalamazoo, MI, USA) [61], and the number of adherent granulocytes was counted in five different $900 \mu \mathrm{m}$ diameter fields of view. For assays on dry fibronectin, the granulocytes adhesion was carried out as above except the plates were air dried after blocking with BSA.

\section{Staining for granulocyte adhesion molecules}

A total of $500 \mu \mathrm{l}$ of granulocytes at $2.0 \times 10^{6}$ cells $/ \mathrm{ml}$ were aliquoted into Eppendorf tubes (precoated with $2 \%$ BSA-RPMI for $1 \mathrm{~h}$ at $37^{\circ} \mathrm{C}$ ) and incubated with $10 \mathrm{ng} / \mathrm{ml}$ or $1 \mathrm{ng} / \mathrm{ml} \mathrm{TNF \alpha ,} 100 \mathrm{ng} / \mathrm{ml} \mathrm{IL-8,} \mathrm{or} 10 \mathrm{ng} / \mathrm{ml}$ or 1 $\mathrm{ng} / \mathrm{ml} \mathrm{GM-CSF}$ in the presence or absence of $10 \mu \mathrm{g} / \mathrm{ml}$ or $60 \mu \mathrm{g} / \mathrm{ml} \mathrm{SAP} \mathrm{for} 1 \mathrm{~h}$ at $37^{\circ} \mathrm{C}$. For the granulocytes that were stained with (anti-human) anti-CD18, antiCD61, or anti-CD44, SAP was added to $30 \mu \mathrm{g} / \mathrm{ml}$. Cells were then washed with ice-cold PBS, collected by centrifugation at $500 \mathrm{~g}$ for 5 minutes, and resuspended in $1 \mathrm{ml}$ of $4 \%$ BSA-PBS. Cells were stained in BSA-coated tubes with $5 \mu \mathrm{g} / \mathrm{ml}$ antibodies against CD11b (BioLegend, San Diego, CA, USA), CD62L (BD Biosciences), CD32 (BD Biosciences), CD18 (BioLegend), CD61 (BD Biosciences), CD44 (BD Biosciences), or mouse IgG1 isotype control (BioLegend) for 30 minutes at $4^{\circ} \mathrm{C}$. The cells were then washed three times in ice-cold PBS, and incubated with $2.5 \mu \mathrm{g} / \mathrm{ml}$ fluorescein isothiocyanate (FITC)-conjugated $\mathrm{F}(\mathrm{ab} /) 2$ goat anti-mouse IgG antibodies (crossadsorbed against human Ig, Southern Biotechnology, Birmingham, 
AL, USA) as described previously [60,62]. The cells were washed three times in ice-cold PBS, resuspended in $200 \mu \mathrm{l}$ 4\% BSA-PBS, and analyzed by flow cytometry.

\section{Hydrogen peroxide production}

Wells of black 96-well cell culture plates (Nalge Nunc, Rochester, NY, USA) were precoated with $50 \mu \mathrm{l}$ of $20 \mu \mathrm{g} / \mathrm{ml}$ plasma fibronectin for $1 \mathrm{~h}$ at $37^{\circ} \mathrm{C}$. The fibronectin was then removed, and the wells were washed three times with $200 \mu \mathrm{l}$ of PBS, and then washed once with Krebs-Ringer phosphate glucose buffer (KRPG) (145 mM NaCl, $4.9 \mathrm{mM} \mathrm{KCl}, 0.54 \mathrm{mM} \mathrm{CaCl}_{2}, 1.2 \mathrm{mM}$ $\mathrm{MgSO}_{4}, 5.8 \mathrm{mM}$ sodium phosphate, and $5.5 \mathrm{mM}$ glucose, $\mathrm{pH}$ 7.35) [11]. A total of $500 \mu \mathrm{l}$ of granulocytes at $1.5 \times 10^{6}$ cells $/ \mathrm{ml}$ in KRPG were incubated in an Eppendorf tube (preincubated with 2\% BSA-KRPG for $2 \mathrm{~h}$ at $37^{\circ} \mathrm{C}$ ) and SAP was added to a final concentration of $30 \mu \mathrm{g} / \mathrm{ml}$. As a control, a similar tube had an equal volume of buffer added to it. These were incubated for 30 minutes at $37^{\circ} \mathrm{C}$. An assay mixture of $100 \mu$ of KRPG, $20 \mu \mathrm{l}$ of $300 \mu \mathrm{M}$ scopoletin (Sigma) in KRPG, $20 \mu \mathrm{l}$ of $10 \mathrm{mM} \mathrm{NaN}_{3}$ in KRPG, and $20 \mu \mathrm{l}$ of $10 \mathrm{U} / \mathrm{ml}$ horseradish peroxidase (Sigma) in KRPG were aliquoted into a well and the plate was equilibrated to $37^{\circ} \mathrm{C}$ for 5 minutes as described previously $[11,63]$. Then, $20 \mu \mathrm{l}$ of granulocytes incubated with or without $30 \mu \mathrm{g} / \mathrm{ml}$ SAP was added to the assay mixture in the presence or absence of $20 \mu \mathrm{l}$ of $1 \mu \mathrm{g} / \mathrm{ml} \mathrm{TNF} \alpha$ in KRPG, $20 \mu \mathrm{l}$ of $1 \mu \mathrm{M}$ fMLP (Sigma) in KRPG, $20 \mu \mathrm{l}$ of $1 \mu \mathrm{M}$ phorbol 12-myristate 13-acetate (PMA) (Sigma) in KRPG, $20 \mu \mathrm{l}$ of $1 \mu \mathrm{M}$ phorbol 12,13-dibutyrate (PDBu) (Sigma) in KRPG, or $20 \mu \mathrm{l}$ of KRPG. The 96-well plate was incubated at $37^{\circ} \mathrm{C}$ and the fluorescence (excitation: $360 \mathrm{~nm}$ emission: $460 \mathrm{~nm}$ ) was monitored every 10 minutes for 3 h using a Synergy MX plate reader (BioTek, Winooski, VT, USA).

\section{Transmigration of granulocytes}

A total of $50 \mu \mathrm{l}$ of granulocytes at $1 \times 10^{6}$ cells $/ \mathrm{ml}$ in $2 \%$ BSA-RPMI was added to the top chamber of a $3 \mu \mathrm{m}$ pore size nylon membrane insert in a 24 well plate (BD) in the presence or absence of $10 \mathrm{nM}$ fMLP, $30 \mu \mathrm{g} / \mathrm{ml}$ SAP, $10 \mathrm{nM}$ fMLP and $30 \mu \mathrm{g} / \mathrm{ml}$ SAP or an equal volume of buffer in 2\% BSA-RPMI. The bottom chambers contained $600 \mu \mathrm{l}$ of $10 \mathrm{nM}$ fMLP in 2\% BSA-RPMI, $600 \mu \mathrm{l}$ of $30 \mu \mathrm{g} / \mathrm{ml} \mathrm{SAP}$ in 2\% BSA-RPMI, $600 \mu \mathrm{l}$ of 10 nM fMLP and $30 \mu \mathrm{g} / \mathrm{ml} \mathrm{SAP} \mathrm{in} \mathrm{2 \%} \mathrm{BSA-RPMI,} \mathrm{or} \mathrm{equal}$ volumes of buffer in $2 \%$ BSA-RPMI. The transmigration was carried out for $2 \mathrm{~h}$ at $37^{\circ} \mathrm{C}$. The top chamber was removed, and the granulocytes that had migrated into the bottom chamber were then counted with a flow cytometer.

\section{Staining for apoptotic granulocytes}

A total of $500 \mu \mathrm{l}$ of granulocytes at $2.0 \times 10^{6}$ cells $/ \mathrm{ml}$ were aliquoted into Eppendorf tubes (precoated with $2 \%$ BSA-RPMI for $1 \mathrm{~h}$ at $37^{\circ} \mathrm{C}$ ) and incubated with $10 \mathrm{ng} / \mathrm{ml}$ or $1 \mathrm{ng} / \mathrm{ml} \mathrm{TNF} \alpha$, or $10 \mathrm{ng} / \mathrm{ml}$ or $1 \mathrm{ng} / \mathrm{ml} \mathrm{GM-CSF}$ in the presence or absence of $60 \mu \mathrm{g} / \mathrm{ml}$ SAP for $22 \mathrm{~h}$ at $37^{\circ} \mathrm{C}$. The cells were then washed with ice-cold PBS, collected by centrifugation at $500 \mathrm{~g}$ for 5 minutes, and resuspended in $1 \mathrm{ml}$ of $4 \%$ BSA-PBS. Cells were stained with $5 \mu \mathrm{g} / \mathrm{ml}$ Alexafluor 488-conjugated annexin $\mathrm{V}$ (Invitrogen) for 30 minutes at $4^{\circ} \mathrm{C}$. The cells were then washed three times in ice-cold PBS, resuspended in $200 \mu \mathrm{l} 4 \%$ BSA-PBS, and analyzed with a flow cytometer.

\section{Murine granulocyte adhesion assay}

C57/BL6 mice (4 weeks old; Jackson Laboratories, Bar Harbor, ME, USA) were housed at the Laboratory Animal Resources and Research facility at Texas A\&M University. Animal procedures were approved by the Institutional Animal Care and Use Committee at Texas A\&M University. Mice were killed and blood was obtained via cardiac puncture. From two to three mice, a total of 2 to $3 \mathrm{ml}$ of blood was collected in an ethylenediaminetetra-acetic acid (EDTA)-containing vacutainer tube (BD) and the red blood cells (RBC) in $2 \mathrm{ml}$ of blood were lysed by adding $1 \mathrm{ml}$ of ammonium chloride/potassium bicarbonate (ACK) lysis buffer (15 mM NH $\mathrm{NH}_{4} \mathrm{Cl} 1 \mathrm{mM} \mathrm{KHCO}_{3}$, $0.01 \mathrm{mM} \mathrm{Na} \mathrm{Na}_{2} \mathrm{EDT}$ ) and incubating for 3 minutes at room temperature. Cells were collected by centrifugation at $500 \mathrm{~g}$ for 5 minutes at room temperature. The pellets were resuspended in $200 \mu \mathrm{l}$ PBS, and $1 \mathrm{ml}$ ACK lysis buffer was added. After 3 minutes, cells were collected by centrifugation. This was then repeated two additional times. Cells were resuspended in $1 \mathrm{ml} \mathrm{PBS}$ and then collected by centrifugation. The cells were then resuspended in $1 \mathrm{ml}$ of $2 \%$ BSA-RPMI. Wells of flat bottom 96-well tissue culture plates (BD) were precoated with $50 \mu \mathrm{l}$ of $20 \mu \mathrm{g} / \mathrm{ml}$ plasma fibronectin (Sigma) in PBS for $1 \mathrm{~h}$ at $37^{\circ} \mathrm{C}$. A granulocyte adhesion assay was carried out in 2\% BSA-RPMI similar to the human granulocyte adhesion assay using $60 \mu \mathrm{g} / \mathrm{ml}$ human SAP instead of $30 \mu \mathrm{g} / \mathrm{ml}$. The adhered cells were stained for Ly6G to distinguish granulocytes from other cell types as described previously [64]. The number of adhered Ly6G-positive granulocytes was then counted as described above.

\section{Granulocyte influx in mice}

C57/BL6 mice (4 weeks old; Jackson) were treated with an oropharyngeal aspiration of $50 \mu \mathrm{l}$ of $0.2 \mathrm{U} / \mathrm{kg}$ or 3 $\mathrm{U} / \mathrm{kg}$ bleomycin (Calbiochem) [65]. The successful aspiration of bleomycin into the lungs was confirmed by listening to the crackling noise heard after the aspiration. At 24 and $48 \mathrm{~h}$ following bleomycin aspiration (days 1 and 2), mice were given an intraperitoneal injection of 
$50 \mu \mathrm{l}$ of $1 \mathrm{mg} / \mathrm{ml} \mathrm{hSAP}$ or $1 \mathrm{mg} / \mathrm{ml} \mathrm{mSAP}$ in $20 \mathrm{mM}$ sodium phosphate buffer or an equal volume of $20 \mathrm{mM}$ sodium phosphate buffer. Mice were killed at day 3 after bleomycin aspiration, and the lungs were perfused with $400 \mu \mathrm{l}$ of PBS three times to collect cells by bronchoalveolar lavage (BAL) as described previously [66]. The cells were collected by centrifugation at $500 \mathrm{~g}$ for 5 minutes, and the supernatants were transferred to Eppendorf tubes. The pooled supernatants were flash frozen with liquid nitrogen, and stored at $-80^{\circ} \mathrm{C}$ until further use. The cells collected from BAL were resuspended in $100 \mu \mathrm{l}$ of $4 \%$ BSA-PBS and counted with a hemacytometer. The cells were then diluted in a total volume of $600 \mu \mathrm{l}$ of $4 \%$ BSAPBS. Then, $100 \mu \mathrm{l}$ of diluted cells were aliquoted into cytospin funnels and were spun onto glass slides (Superfrost plus white slides, VWR, West Chester, PA, USA) at $400 \mathrm{~g}$ for 5 minutes using a cytospin centrifuge (Shandon, Cheshire, UK). These cells were then air dried, and stained with $5 \mu \mathrm{g} / \mathrm{ml}$ anti-mouse Ly6G (BioLegend) as previously described [64]. After staining the cells, the number of cells positive for Ly6G per 200 cells was counted. The percentage of positive cells was then multiplied by the total number of cells recovered from the BAL to obtain the number of granulocytes in the BAL. The mice were used in accordance with guidelines published by the National Institutes of Health, and the protocol was approved by the Texas A\&M University Animal Use and Care Committee.

\section{Immunohistochemistry}

After BAL, lungs were inflated with prewarmed optimal cutting temperature (OCT) compound (VWR) and then embedded in OCT, frozen on dry ice, and stored at $-80^{\circ} \mathrm{C}$ as described previously [52]. Lung tissue sections $(6 \mu \mathrm{m})$ were prepared and immunohistochemistry was performed as described previously [52] except slides were incubated with $2.5 \mu \mathrm{g} / \mathrm{ml}$ primary antibodies in $4 \%$ BSA-PBS for 60 minutes. The lung sections were stained for Ly6G (BioLegend) to detect granulocytes, CD11b (BioLegend) to detect macrophages, and CD45 (BioLegend) to detect all leukocytes. Isotype-matched mouse irrelevant antibodies were used as controls. Slides were then washed three times with PBS over 30 minutes and incubated with $1.25 \mu \mathrm{g} / \mathrm{ml}$ biotinylated mouse $\mathrm{F}\left(\mathrm{ab}^{\prime}\right)_{2}$ anti-rat IgG in $4 \%$ BSA-PBS for 30 minutes. Slides were then washed three times in PBS over 30 minutes and incubated with a 1:500 dilution of streptavidin alkaline phosphatase (Vector Laboratories) in 4\% BSA-PBS for 30 minutes. Staining was developed with a VectorRed Alkaline Phosphatase Kit (Vector Laboratories) for 10 minutes. Slides were then mounted as described previously [52].

\section{Statistics}

Statistical analysis was performed using Prism (GraphPad Software, San Diego, CA, USA). Statistical significance was determined using either analysis of variance (ANOVA) or t test, and significance was defined as $P<0.05$.

\section{Results}

\section{Characterization of isolated granulocytes}

Human granulocytes were isolated with lympholyte poly. This isolation technique generated $80 \pm 2 \%$ pure granulocytes, with small particulate matter accounting for much of the contamination (Figure 1A). The number of non-granulocyte cells was significantly lower than the number of granulocytes obtained (Figure 1B). When isolated cells were further analyzed for their nuclear morphology using DAPI staining, the number of granulocytes was significantly more than the number of nongranulocyte cells (Figure 1C,D). Eosin/methylene blue staining of the isolated granulocytes indicated that there were consistently less than $4 \%$ eosinophils and no detectable basophils, with the majority of the cells neutrophils (D Pilling, Texas A\&M University, College Station, Texas USA, personal communication). These results suggest that lympholyte poly effectively isolates granulocytes from whole blood.

\section{SAP inhibits granulocyte spreading}

Granulocyte spreading allows granulocytes to polarize and migrate towards the site of injury [67]. To determine the effect of SAP on granulocyte spreading, human PBMCs were incubated with cell debris. The PBMC supernatant (which should contain cell debris as well as PBMCderived signals elicited in response to debris) was added to human granulocytes in the presence or absence of SAP. We observed spreading granulocytes in the controls, which could have been an effect of laying granulocytes directly on a plastic tissue culture plate (Figure 2A). SAP appeared to decrease granulocyte spreading (Figure 2A). PBMC supernatant increased the numbers of spreading granulocytes (Figure 2A,B), and the addition of SAP inhibited the PBMC supernatant-induced granulocyte spreading (Figure 2B). These results suggest that SAP inhibits granulocyte spreading.

\section{SAP inhibits human granulocyte adhesion}

TNF $\alpha$ increases the adherence of granulocytes on a variety of extracellular matrices $[11,68]$. Since SAP inhibited granulocyte spreading, we examined the effect of SAP on granulocyte adhesion. Human granulocytes were incubated with or without SAP, and were then incubated with or without TNF $\alpha$ in plates precoated with plasma fibronectin, cellular fibronectin, BSA, or air-dried cellular fibronectin. As observed previously, incubation with TNF $\alpha$ increased the number of granulocytes that adhered to the wells (Figure 3A-D). In the absence of TNF $\alpha$, SAP decreased the number of adhered granulocytes to $43.0 \pm$ $7.4 \%$ compared to the control (mean \pm SEM, $\mathrm{n}=23$, 


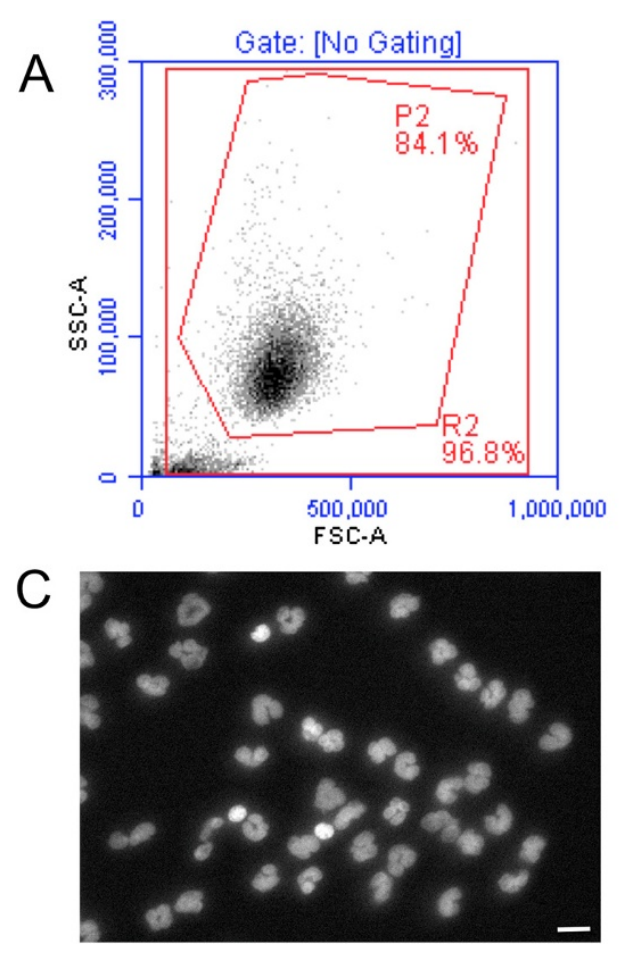

B
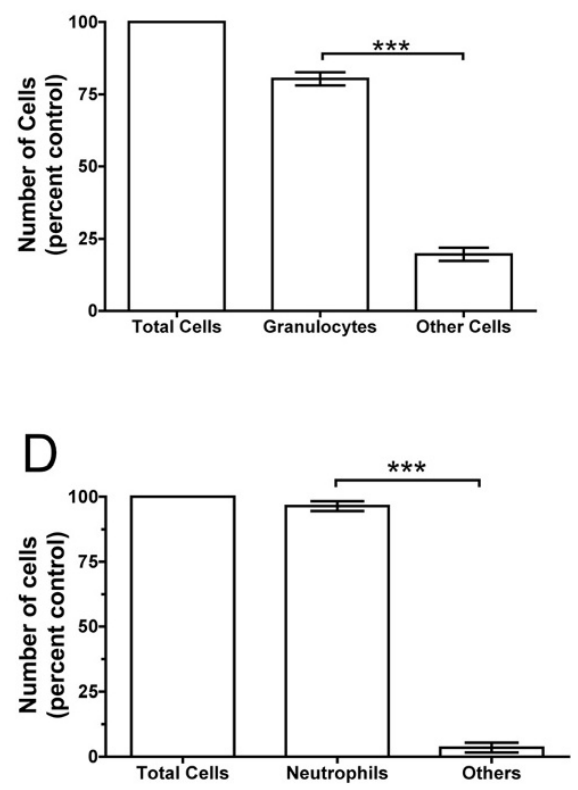

Figure 1 Characterization of isolated granulocytes. (A) Flow cytometry showing forward-scatter ( $\mathrm{x}$-axis) and side-scatter characteristics (y-axis) from 10,000 events. The P2 area shows the granulocyte population. (B) The number of granulocytes isolated exceeds the number of other nongranulocyte cells. The results are mean \pm SEM of percentage total cells $(n=3$ separate experiments). (C) Human granulocytes were seeded on a glass slide and spread by centrifugation. Cells were stained with 4',6-diamidino-2-phenylindole (DAPI) to visualize nuclei. Bar is $20 \mu \mathrm{m}$. (D) The number of granulocytes was counted based on nuclear morphology. There were fewer non-granulocyte cells compared to the isolated granulocytes. The results are mean \pm SEM of percentage total cells $\left(n=3\right.$ separate experiments). ${ }^{* *} p<0.001$ (t test).

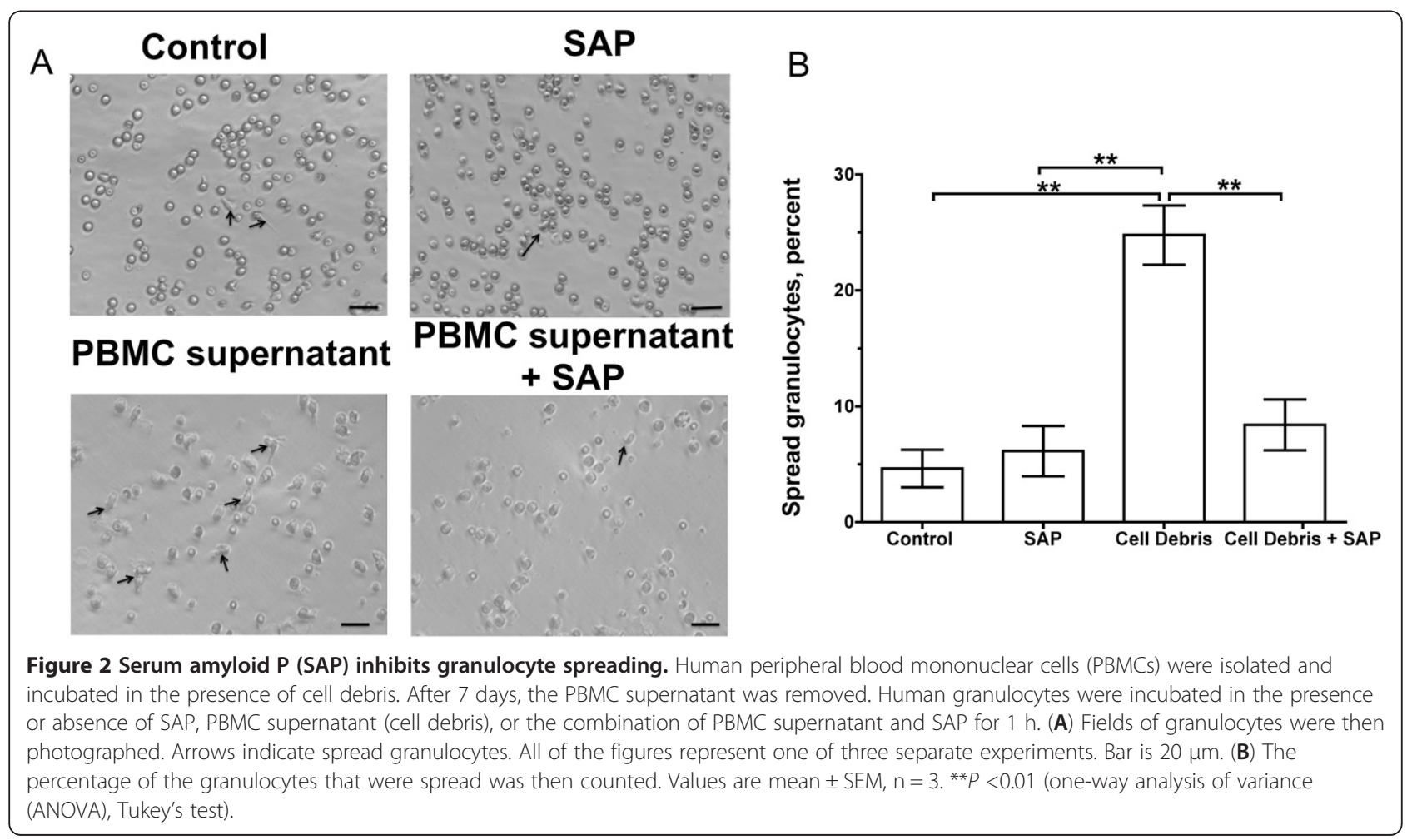




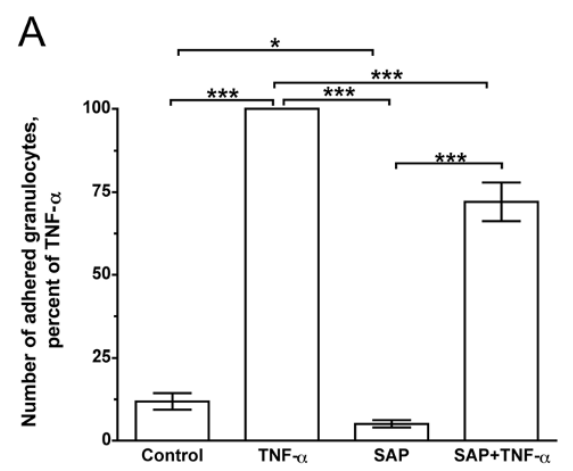

C

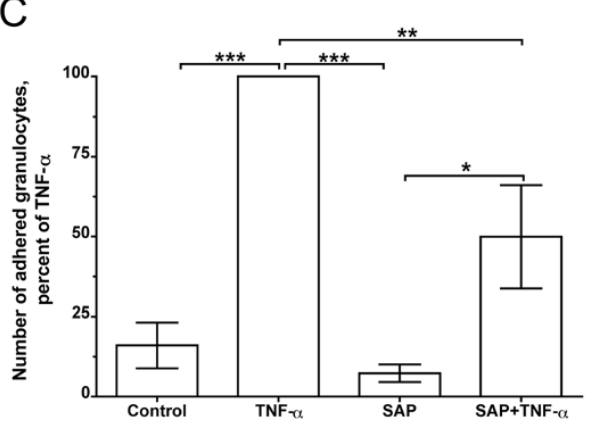

B
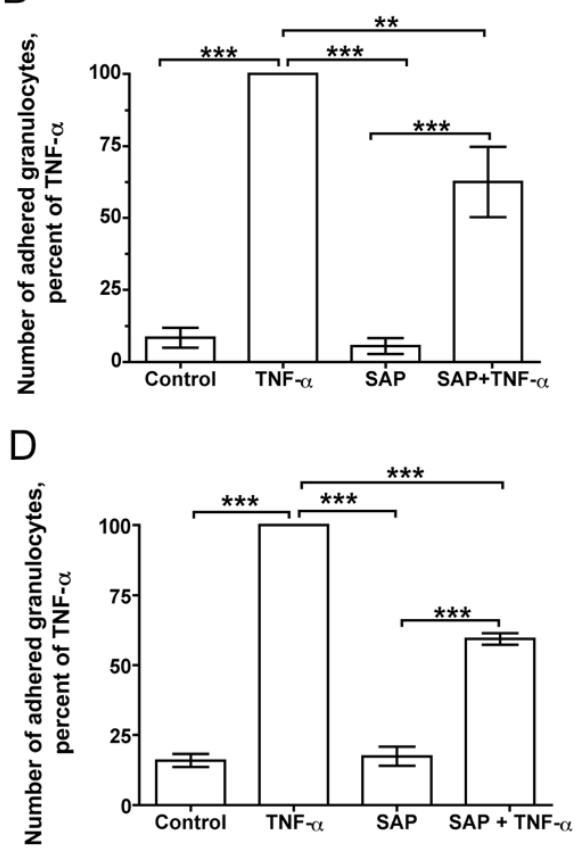

Figure 3 Serum amyloid P (SAP) inhibits granulocyte adhesion. (A) First, 96-well tissue culture plates were coated with plasma fibronectin. Human granulocytes were treated with or without SAP and/or human tumor necrosis factor (TNF)a, incubated in the plate, and adhered granulocytes were counted. Values are mean \pm SEM, $n=23$. (B) A similar assay was performed using plates coated with cellular fibronectin. Values are mean $\pm S E M, n=5$. (C) A similar assay was performed using plates coated with bovine serum albumin (BSA). Values are mean $\pm S E M, n=4$. (D) A similar assay was performed using plates coated with cellular fibronectin, and then air dried. Values are mean $\pm \mathrm{SEM}, \mathrm{n}=3$. ${ }^{*} P<0.05,{ }^{*} P<0.01$, ***P $<0.001$ (one-way analysis of variance (ANOVA), Tukey's test).

$P<0.001$ by $\mathrm{t}$ test) on plasma fibronectin and decreased the number of adhered granulocytes to $64.1 \pm 14.9$ compared to the control on cellular fibronectin $(\mathrm{n}=5, P<0.05$ by $t$ test). However, in wells coated with BSA or air-dried fibronectin, there was no significant difference between control and SAP treatment. SAP significantly inhibited the TNF $\alpha$-induced adhesion of granulocytes to plasma fibronectin, cellular fibronectin, BSA, and air-dried cellular fibronectin (Figure 3A-D). These results suggest SAP inhibits granulocyte adhesion on native cellular and plasma fibronectin, and that SAP inhibits TNF $\alpha$-induced granulocyte adhesion on a wider variety of surfaces.

\section{SAP inhibits murine granulocyte adhesion}

Since we found that human SAP can inhibit human granulocyte adhesion induced by TNF $\alpha$, we examined if human SAP could also inhibit murine granulocyte adhesion. Murine granulocytes were incubated with or without human SAP and TNF $\alpha$ in plates precoated with plasma fibronectin. TNF $\alpha$ increased the number of adhered granulocytes (Figure 4). In the absence of TNF $\alpha$, SAP had no significant effect on granulocyte adhesion (Figure 4). However, SAP significantly inhibited TNF $\alpha$-induced granulocyte adhesion to plasma fibronectin (Figure 4).

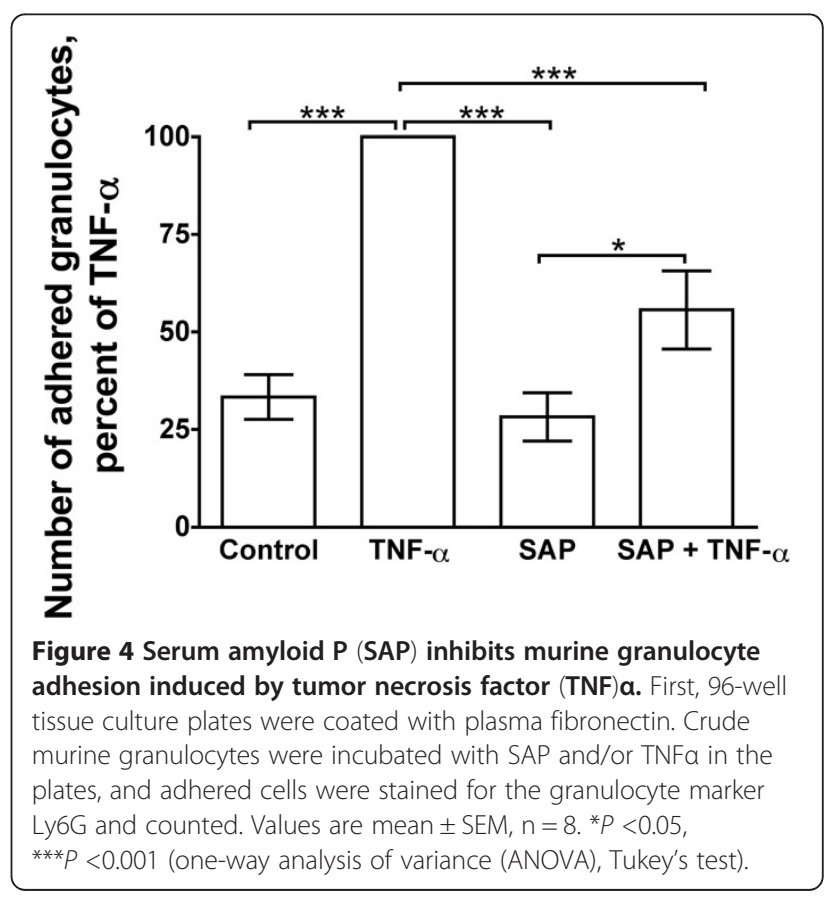




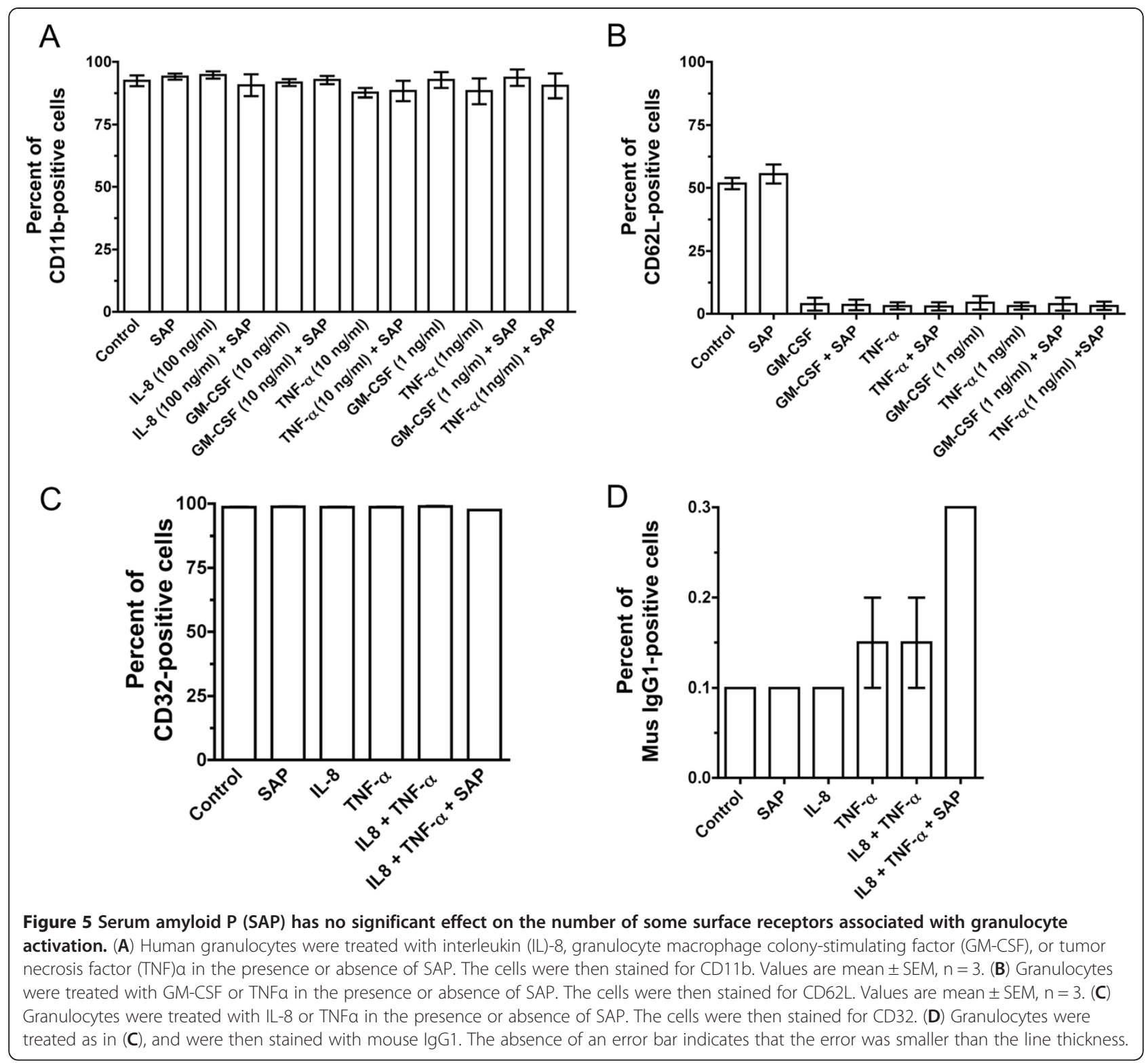

SAP has no effect on levels of some adhesion molecules To determine how SAP affects adhesion, we analyzed receptors such as $\mathrm{CD} 11 \mathrm{~b}$ and $\mathrm{CD} 62 \mathrm{~L}$ whose levels change in activated granulocytes such as neutrophils. Granulocytes were treated with TNF $\alpha$, IL-8, or GM-CSF in the presence or absence of SAP, and the cells were stained for CD11b, CD62L, and CD32 (FcyRII) as a control. There was no significant effect of any treatment on the number of CD11b-positive cells (Figure 5A). IL-8 in the presence or absence of SAP had no effect on the levels of CD11b or CD62L compared to untreated granulocytes (Figure 6A). As shown previously, TNF $\alpha$ and GM-CSF induced increased levels of CD11b (Figure 6A) $[10,13,69]$, but SAP had no effect on the activation. As observed previously, TNF $\alpha$ and GM-CSF decreased the number and the levels of CD62L-positive cells, [70] but SAP had no effect on the basal or stimulated CD62L levels (Figures $5 \mathrm{~B}$ and $6 \mathrm{~A}$ ). There was no significant effect on the levels of CD32 or mouse IgG1 (control) staining when granulocytes were treated with TNF $\alpha$ or IL- 8 in the presence or absence of SAP (Figures $5 \mathrm{C}, \mathrm{D}$ and $6 \mathrm{~B})$. Together, the data indicate that although TNF $\alpha$ and GM-CSF alter levels of CD11b and CD62L on granulocytes $[10,13,69,70]$, the addition of SAP has no obvious effect on the levels of these adhesion molecules or CD32.

Since SAP had no effect on the levels of the surface receptors $\mathrm{CD} 11 \mathrm{~b}$ or $\mathrm{CD} 62 \mathrm{~L}$, we examined the levels of 




other adhesion molecules such as CD18, CD61, or CD44 [71]. As described previously, TNF $\alpha$ increased the levels of CD18 and decreased levels of CD44 (Figure 7) $[10,72]$, but there was no significant effect of TNF $\alpha$ on the levels of CD61. Similarly, fMLP slightly increased the levels of CD18 (Figure 7) but there was no significant effect on the levels of CD61 or CD44. SAP had no effect on the basal or stimulated levels of CD18, CD44, or CD61. Together, the data indicate that although SAP affects granulocyte adhesion, it does not affect cell surface levels of CD11b, CD62L, CD18, CD61, or CD44.

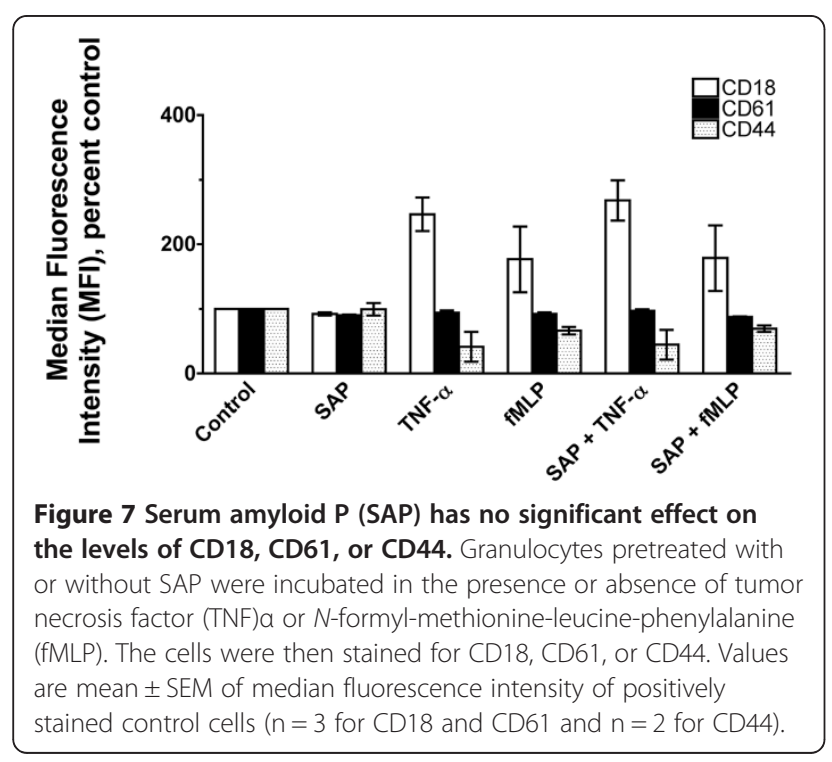

\section{SAP has no detectable effect on hydrogen peroxide production}

Activated granulocytes release hydrogen peroxide to kill microbes such as bacteria [55], but excessive release of hydrogen peroxide can further damage an injured tissue. To examine whether SAP can inhibit the production of hydrogen peroxide from unstimulated granulocytes or granulocytes stimulated by TNF $\alpha$, fMLP, PDBu, or PMA, we examined the change in the fluorescence intensity of scopoletin, a fluorescent molecule that gets modified by hydrogen peroxide. To inhibit hydrogen peroxide consumption by the granulocytes, this assay uses sodium azide to inactivate myeloperoxidase and catalase, and release the intracellular hydrogen peroxide to the media [73]. As previously observed, in control cells the extracellular hydrogen peroxide levels increased with time, which could have been the release of intracellular hydrogen peroxide since sodium azide will result in the leakage and release of intracellular hydrogen peroxide [73]. Nevertheless, the production of hydrogen peroxide when cells were treated with TNF $\alpha$, fMLP, PDBu, or PMA exceeded the production of hydrogen peroxide in control cells (Figure 8). As previously observed, SAP had no significant effect on the production of hydrogen peroxide induced by fMLP (Figure $8 \mathrm{~A}$ ). In addition, SAP had no significant effect on the production of hydrogen peroxide induced by TNF $\alpha$ (Figure $8 \mathrm{~B}$ ), $\mathrm{PDBu}$ (Figure 8C), or PMA (Figure 8D). Together, the data indicate that although SAP affects granulocyte adhesion, it does not appear to affect granulocyte hydrogen peroxide production. 


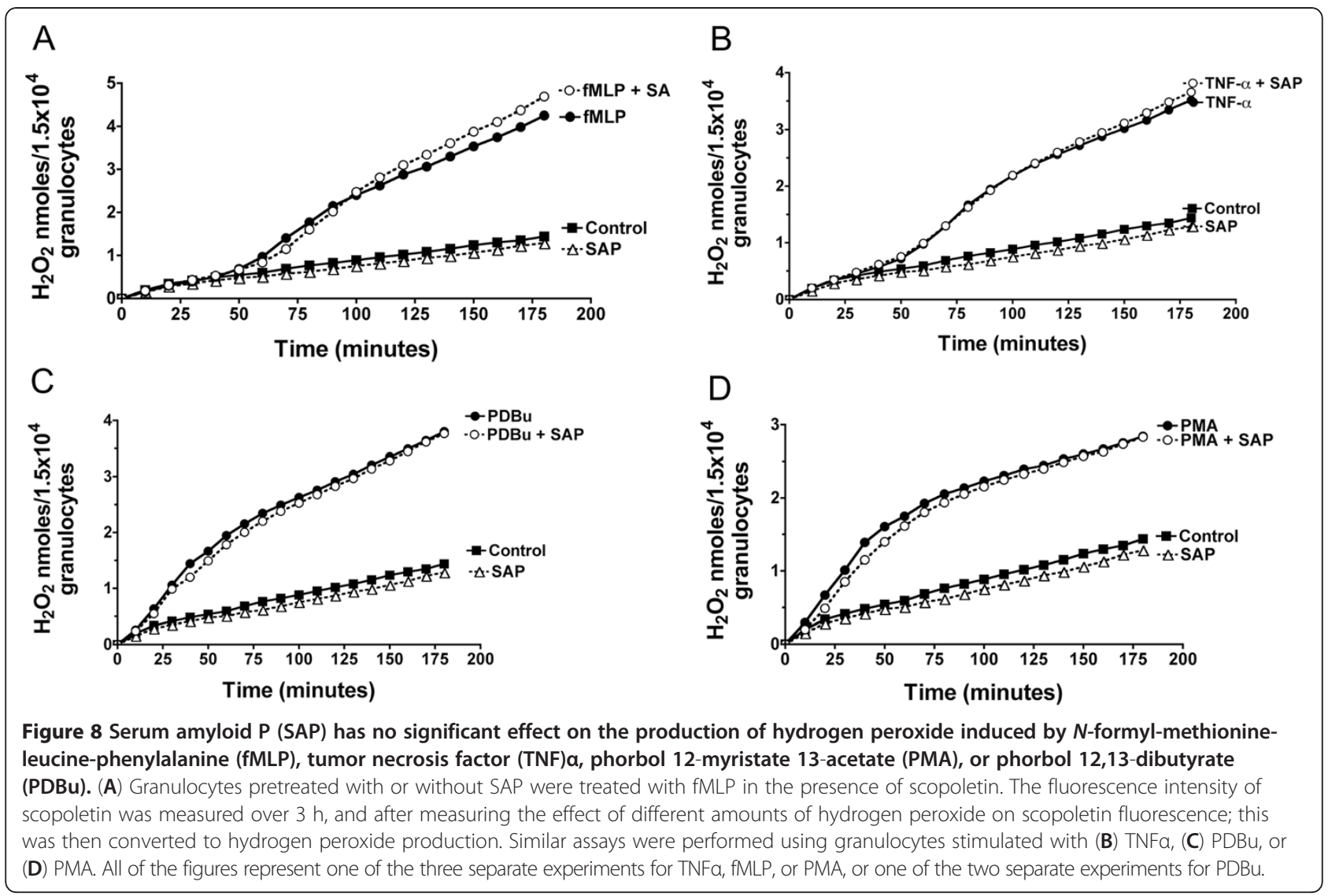

SAP has no detectable effect on the migration of granulocytes

The formyl peptide fMLP induces the migration of granulocytes [74]. To determine the role of SAP in granulocyte migration, we carried out migration assays using a Boyden chamber. Granulocytes were placed on a porous membrane and the bottom of the membrane touched a solution containing buffer or fMLP in the presence or absence of SAP. fMLP significantly increased the number of granulocytes that migrated across the porous membrane, while SAP had no effect on the migration of granulocytes or the migration of granulocytes caused by fMLP (Figure 9).

\section{SAP has no effect on the apoptosis of granulocytes}

Phosphatidylserine gets exposed from the inner surface of the plasma membrane during apoptosis where there is loss of phospholipid asymmetry [75]. Annexin $\mathrm{V}$ is a protein that binds to phosphatidylserine, and we can use a fluorescent dye conjugated to annexin $\mathrm{V}$ to identify apoptotic cells [76]. Granulocytes were treated with TNF $\alpha$ or GM-CSF in the presence or absence of SAP, and the cells were stained with Alexafluor 488-conjugated annexin $\mathrm{V}$. There was no significant effect on the percentage of annexin $\mathrm{V}$-stained cells in all of the conditions except for the cells treated with $10 \mathrm{ng} / \mathrm{ml}$ GM-CSF
(Figure 10). GM-CSF-treated cells had a decreased percentage of annexin V-positive cells compared to other conditions, which matches previous observations that GM-CSF delays apoptosis of granulocytes such as neutrophils [77]. SAP had no significant effect on the percentage

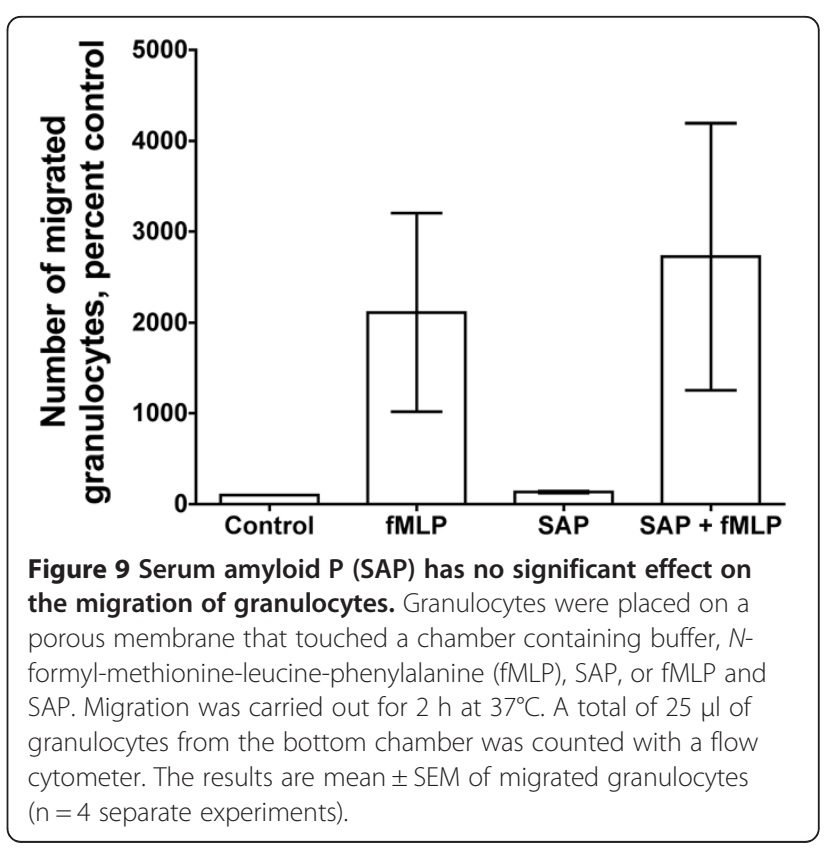






Figure 10 Serum amyloid $\mathrm{P}$ (SAP) has no effect on granulocyte apoptosis. Granulocytes were treated with granulocyte macrophage colony-stimulating factor (GM-CSF) $(10 \mathrm{ng} / \mathrm{ml}$ or $1 \mathrm{ng} / \mathrm{ml})$ or tumor necrosis factor (TNF)a $(10 \mathrm{ng} / \mathrm{ml}$ or $1 \mathrm{ng} / \mathrm{ml})$ in the presence or absence of SAP $(60 \mu \mathrm{g} / \mathrm{ml})$ for $22 \mathrm{~h}$ at $37^{\circ} \mathrm{C}$. The cells were then stained with annexin $\mathrm{V}$ and analyzed by flow cytometry. The results are mean \pm SEM of percentage positive cells ( $n=3$ separate experiments).

of annexin V-positive cells under all tested conditions, suggesting that SAP has no obvious effect on granulocyte apoptosis.

\section{SAP specifically inhibits the accumulation of Ly6G-positive cells in lungs of mice treated with bleomycin}

Since SAP inhibits granulocyte adhesion, we examined the effect of SAP on bleomycin-induced granulocyte accumulation in the lungs of mice. Mice were treated with or without $0.2 \mathrm{U} / \mathrm{kg}$ bleomycin on day 0 and were then given intraperitoneal injections of SAP on days 1 and 2 . On day 3 , the mice were killed and cells from the lungs were collected by BAL. There was no statistically significant difference in the number of cells collected from BAL of control, saline, $0.2 \mathrm{U} / \mathrm{kg}$ bleomycin and buffer, $0.2 \mathrm{U} / \mathrm{kg}$ bleomycin and human SAP, or $0.2 \mathrm{U} / \mathrm{kg}$ bleomycin and mouse SAP (Figure 11A). Cells collected from the BAL of mice were then stained with anti-mouse Ly6G (this stains neutrophils and some eosinophils) [78,79]. There was an increased number of Ly6G-positive cells in the BAL from mice treated with $0.2 \mathrm{U} / \mathrm{kg}$ bleomycin and buffer compared to the number of Ly6G-positive cells in the BAL from control (untreated mice) or saline-treated mice (Figure 11C). However, there was a decreased number of Ly6G-positive cells in the BAL from mice treated with $0.2 \mathrm{U} / \mathrm{kg}$ bleomycin and human SAP or $0.2 \mathrm{U} / \mathrm{kg}$ bleomycin and mouse SAP when compared to the BAL from mice treated with $0.2 \mathrm{U} / \mathrm{kg}$ bleomycin and buffer (Figure 11B,C). There was no significant difference between the number of Ly6G-positive cells in the BAL from mice treated with $0.2 \mathrm{U} / \mathrm{kg}$ bleomycin and human SAP or $0.2 \mathrm{U} / \mathrm{kg}$ bleomycin and mouse SAP when compared to control (untreated mice) or saline-treated mice. We stained lung sections with Ly6G after BAL to detect granulocytes remaining in the lungs after BAL. There was an increased number of Ly6G-positive cells in the lung sections after BAL in mice treated with $0.2 \mathrm{U} / \mathrm{kg}$ bleomycin and buffer compared to the number of Ly6G-positive cells in the lung sections from control (untreated mice), salinetreated mice, or mice treated with $0.2 \mathrm{U} / \mathrm{kg}$ bleomycin and human SAP (Figure 11D,E).

We also similarly treated mice with $3 \mathrm{U} / \mathrm{kg}$ bleomycin. Previous results from our laboratory have shown that human SAP is more potent at inhibiting the differentiation of monocytes to fibrocytes than mouse SAP [51], so we decided to only use human SAP. There was no statistically significant difference between the number of cells collected from the BAL of control or saline-treated mice (Figure 12A). However, there were an increased number of cells collected in the BAL from mice treated with $3 \mathrm{U} / \mathrm{kg}$ bleomycin and buffer or $3 \mathrm{U} / \mathrm{kg}$ bleomycin and human SAP when compared to control or salinetreated mice (Figure 12A). There was also an increased number of Ly6G-positive cells in the BAL from mice treated with $3 \mathrm{U} / \mathrm{kg}$ bleomycin and buffer when compared to the number of Ly6G-positive cells in the BAL from control or saline-treated mice (Figure 12B,C). There was a decreased number of Ly6G-positive cells in the BAL from mice treated with $3 \mathrm{U} / \mathrm{kg}$ bleomycin and human SAP when compared to the number of Ly6Gpositive cells in the BAL from mice treated with $3 \mathrm{U} / \mathrm{kg}$ bleomycin and buffer (Figure 12B,C). However, there was no statistically significant difference in Ly6Gpositive cells in the BAL from mice treated with $3 \mathrm{U} / \mathrm{kg}$ bleomycin and human SAP when compared to the Ly6G-positive cells in the BAL from control or salinetreated mice (Figure 12C). When lung sections were stained with Ly6G after BAL to detect granulocytes remaining in the lungs after BAL, there was an increased number of Ly6G-positive cells in the lung sections of mice treated with $3 \mathrm{U} / \mathrm{kg}$ bleomycin and buffer compared to the number of Ly6G-positive cells in the lung sections from control (untreated mice), saline-treated mice, or mice treated with $3 \mathrm{U} / \mathrm{kg}$ bleomycin and human SAP (Figure 12D,E).

For both 0.2 and $3 \mathrm{U} / \mathrm{kg}$ bleomycin followed by buffer injections, there were more granulocytes observed in the lung sections compared to the lung sections from the bleomycin followed by human SAP treatment group (Figures 11D,E and 12D,E). This indicates that if we had been able to obtain all of the pulmonary granulocytes, the difference between bleomycin/buffer injections and bleomycin/SAP injections would have been even greater than the differences shown in Figures $11 \mathrm{C}$ and $12 \mathrm{C}$. We further analyzed the lung sections for macrophages and leukocytes using anti-CD11b (in mice, Cd11b is a macrophage marker) and anti-CD45 antibodies (Figure 13). 


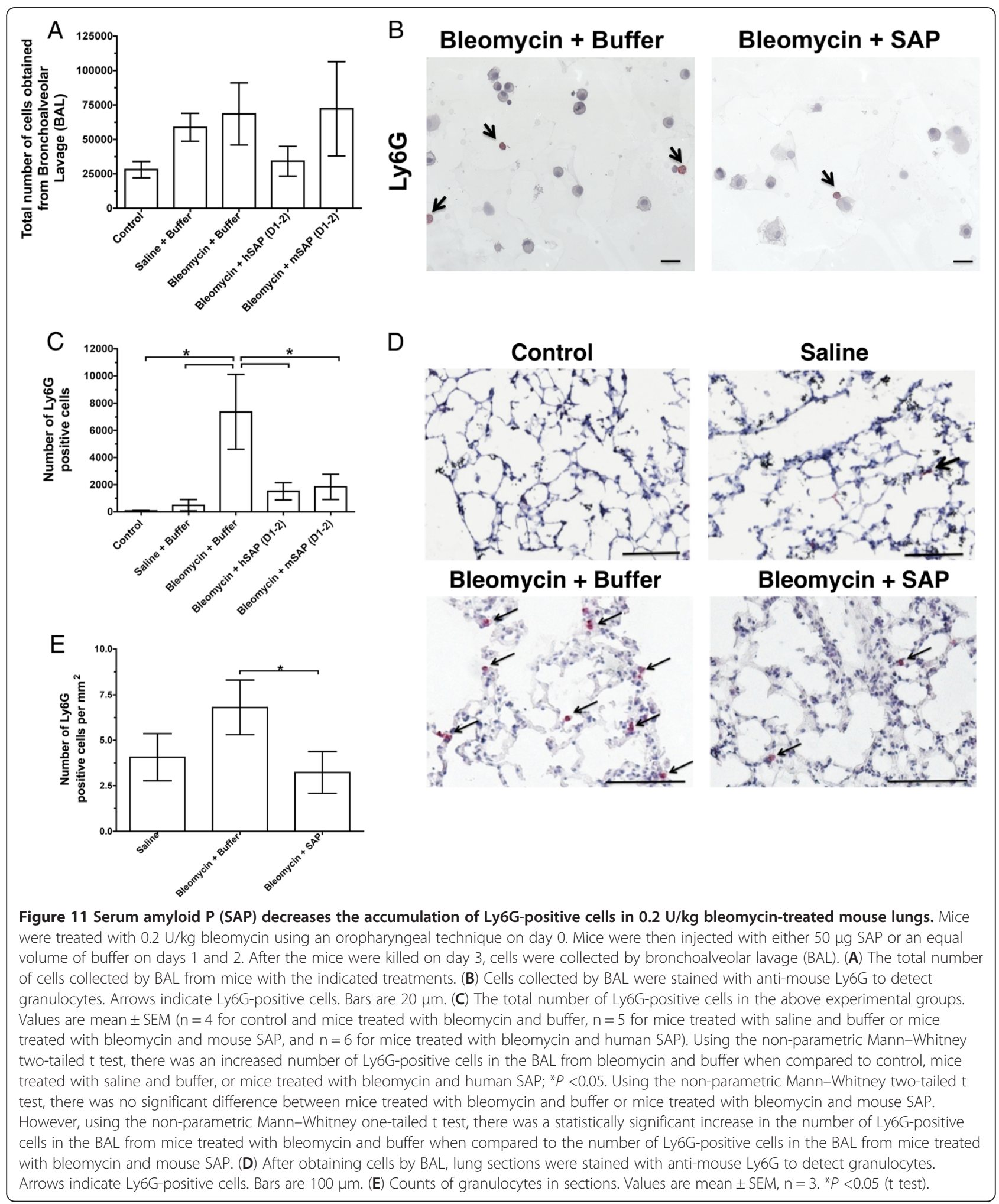




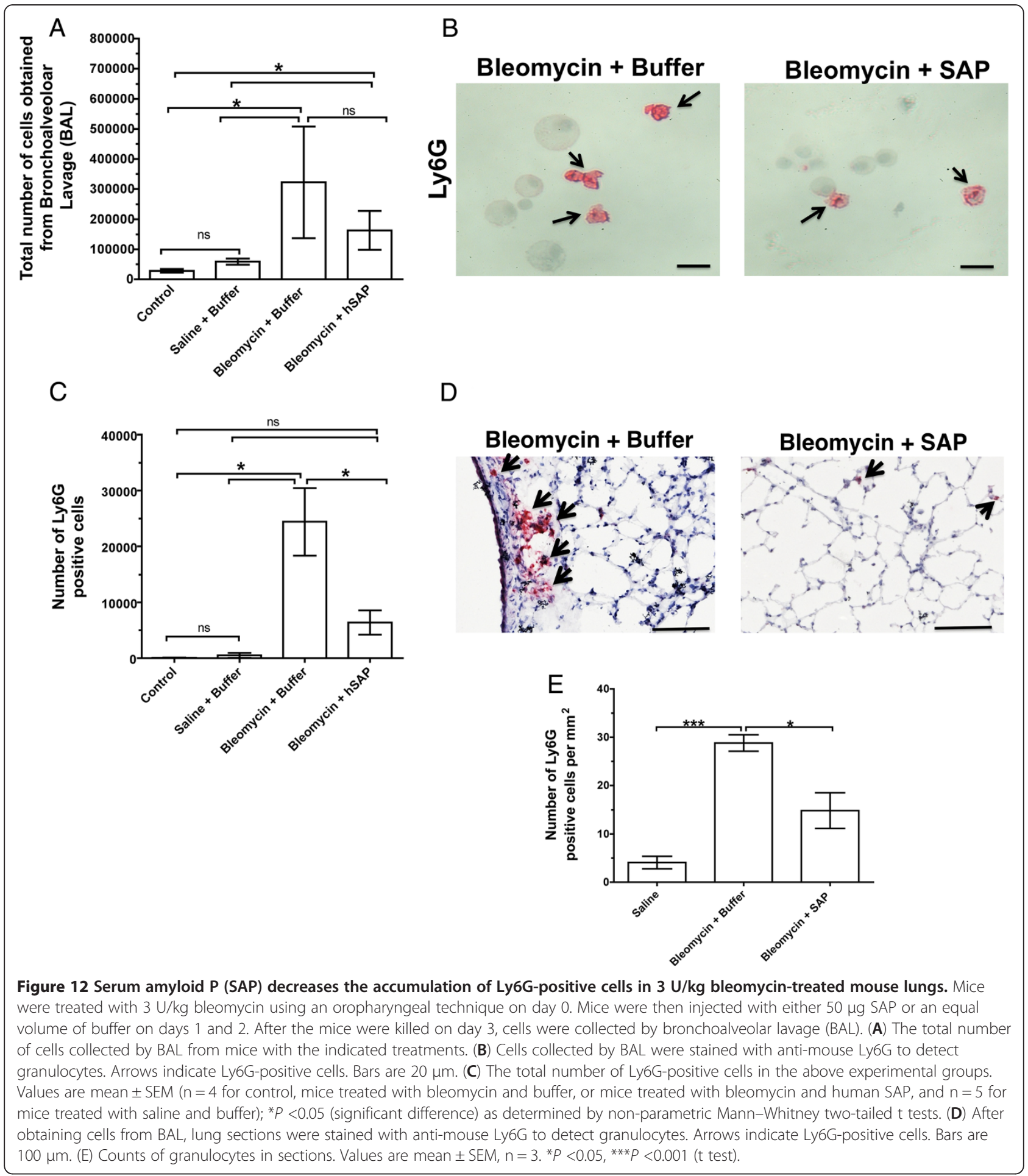

When lung sections were stained for CD11b or CD45, there was no difference between CD11b-positive cells or CD45-positive cells in the lung sections from mice treated with $0.2 \mathrm{U} / \mathrm{kg}$ bleomycin and buffer or mice treated with $0.2 \mathrm{U} / \mathrm{kg}$ bleomycin and human SAP (Figure 13). Our results therefore suggest that at 3 days, SAP has no effect on the bleomycin-induced accumulation of macrophages or other leukocytes in the lungs, but SAP reduces the bleomycin-induced accumulation of granulocytes in the lungs. However, SAP injections do reduce bleomycininduced leukocyte infiltration by day 14 or day 21 [52]. It is possible that at an early injury stage, SAP only affects 


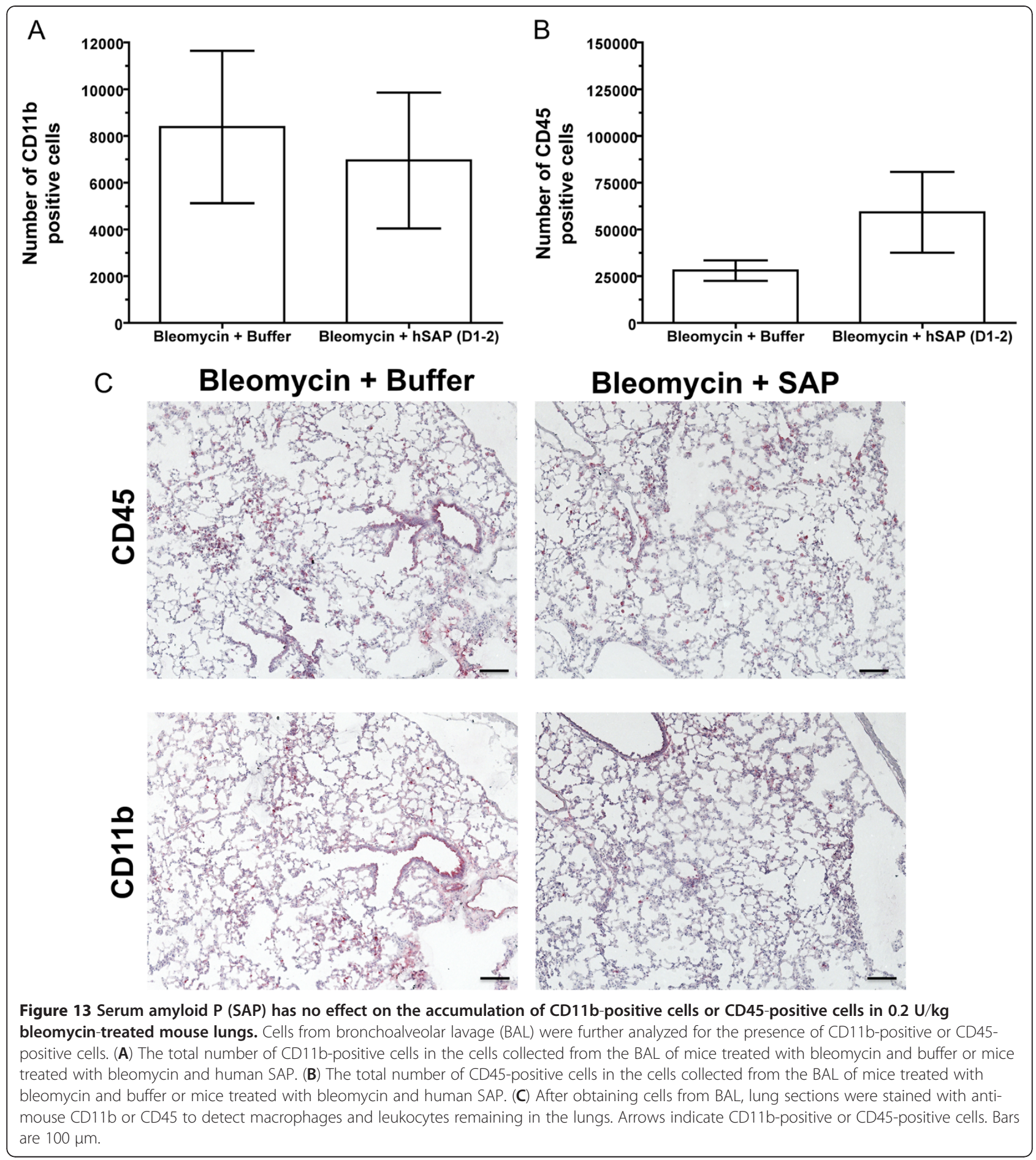

the infiltration of granulocytes, but at later injury stage, SAP can inhibit the overall leukocyte infiltration induced by bleomycin.

\section{Discussion}

We found that SAP inhibits cell debris-induced granulocyte spreading and TNF $\alpha$-induced granulocyte adhesion on different extracellular matrices. However, SAP has no effect on the surface levels of granulocyte adhesion molecules such as CD11b, CD62L, CD18, or CD44 that are affected by granulocyte activating factors such as TNFo, GM-CSF, or fMLP. SAP also has no effect on the production of hydrogen peroxide induced by granulocyte activating factors such as PMA, PDBu, fMLP, or TNFa. 
In addition, SAP did not have a significant effect on fMLP-induced granulocyte migration. Nevertheless, intraperitoneal injections of SAP significantly reduced the number of granulocytes that accumulate in the lungs of mice treated with bleomycin.

A previous report found that SAP acts as a granulocyte chemoattractant, increases granulocyte adhesion, and increases the percentage of granulocytes expressing CD11b, CD18, and $\alpha 5 \beta 1$ [58]. However, a different group found that SAP inhibits the binding of human granulocyte to TNF $\alpha$-stimulated human umbilical vein endothelial cells [59]. In this report, we find that SAP does not act as a granulocyte chemoattractant, tends to decrease granulocyte adhesion, and does not affect the percentage of granulocyte expressing CD11b and CD18. Given that a variety of factors can activate granulocytes, induce granulocyte chemotaxis and increase granulocyte adhesion, we hypothesize that the SAP used in the first report may have been contaminated with a small amount of some material that activated the granulocytes.

Other pentraxin family proteins also inhibit granulocytes such as neutrophil accumulation in animal models of acute lung injury (ALI) or acute respiratory distress syndrome (ARDS) [37]. CRP and PTX3 also decrease the number of neutrophils that accumulate in injured lungs [32,37]. CRP inhibits neutrophil adhesion and chemotaxis [37]. Administering CRP intravenously 10 minutes before the intratracheal instillation of the neutrophil chemotactic agent C5a reduces neutrophil accumulation in lungs [35]. CRP inhibits L-selectin-mediated neutrophil adhesion on TNF $\alpha$ activated endothelial cells by inducing L-selectin shedding from neutrophils. CRP peptide 201-206 mediates the antiadhesive action through CD32 [33]. Both native CRP and CRP peptide 201-206 prevent neutrophil chemotaxis towards fMLP by inhibiting fMLP-induced p38 mitogen-activated protein (MAP) kinase activity [36]. Similarly, pretreating mice intravenously with PTX3 reduces the number of neutrophils in acid-induced acute lung injury in mice [32]. PTX3 deficiency also increases the number of neutrophils in the lungs of mice treated with lipopolysaccharide (LPS) [34]. PTX3 blocks the interaction of P-selectin glycoprotein ligand-1 (PSGL-1) on neutrophils from interacting with P-selectin on the activated endothelial cells and causes neutrophil detachment rather than arrest to prevent neutrophil migration [32]. An intriguing possibility is that the three pentraxins (SAP, CRP, and PTX3) may use a common mechanism to inhibit granulocytes such as neutrophil adhesion.

SAP prevents the accumulation of granulocytes in the lungs of bleomycin-injured mice. Since SAP inhibits granulocytes adhesion, it is probable that SAP reduces the accumulation of granulocytes by dampening the interaction of granulocytes with extracellular matrices. We still do not know the granulocyte adhesion receptors that are affected by SAP. One possibility is that SAP affects $\beta 1$ integrins such as $\alpha 2 \beta 1, \alpha 5 \beta 1, \alpha 6 \beta 1$, or $\alpha 9 \beta 1$ that are found on granulocytes and can recognize different extracellular matrices [80-83].

\section{Conclusions}

We found that SAP, a constitutive component of blood, is a granulocyte adhesion inhibitor. Furthermore, we found that injections of SAP decrease granulocyte levels in the lungs in a murine model of ARDS. We hypothesize that SAP allows granulocytes to sense whether they are in the blood or in a tissue, and that increasing serum SAP levels, for instance by injection, may be a possible therapeutic for neutrophil-associated diseases such as ARDS.

\section{Abbreviations}

ARDS: Acute respiratory distress syndrome; BAL: Bronchoalveolar lavage; BSA: Bovine serum albumin; CRP: C-reactive protein; fMLP: N-formylmethionine-leucine-phenylalanine; GM-CSF: Granulocyte macrophage colony stimulating factor; ICAM-1: Intracellular adhesion molecule-1; IL: Interleukin; KRPG: Krebs-Ringer phosphate glucose buffer; LXA4: Lipoxin A4;

LXB4: Lipoxin B4; PTX3: Pentraxin-3; PBMCs: Peripheral blood mononuclear cells; PMA: Phorbol 12-myristate 13-acetate; PDBu: Phorbol 12,13-dibutyrate; PSGL-1: P-selectin glycoprotein ligand-1; SAP: Serum amyloid P; SFM: Serumfree media; TNFa: Tumor necrosis factor a.

\section{Competing interests}

RHG, DR and ASM filed an invention disclosure to Texas A\&M University and Rice University on the use of SAP to inhibit neutrophil adhesion and as a possible therapy for acute respiratory distress syndrome and other neutrophil-driven diseases. The two universities have filed a provisional patent application on this disclosure. In addition, RHG is a coinventor on patents for the use of SAP as a therapeutic for fibrosing diseases, and patents on the use of SAP-depleting materials to enhance wound healing $\mathrm{RHG}$ is a member of the Science Advisory Board of, and has stock options from, Promedior, a start-up company that is developing serum amyloid $P$ as a therapeutic for fibrosing diseases, and receives a share of milestone payments made by Promedior to Rice University.

\section{Authors' contributions}

ASM conceived and designed experiments, performed experiments, analyzed data and wrote the paper. DR conceived and designed experiments, performed experiments, and analyzed data. DB conceived and designed experiments, performed experiments, and analyzed data. RHG conceived and designed experiments, performed experiments, analyzed data and edited the manuscript. All authors read and approved the final manuscript.

\section{Acknowledgements}

We thank Varsha Vakil, Rice University and the Beutel Student Health Center Texas A\&M University for assistance with the blood collection. We also thank Dr Darrell Pilling and Michael White, Texas A\&M University for assistance with the oropharyngeal aspiration and bronchoalveolar lavage on mice, and Darrell Pilling for granulocyte staining data. This work was supported by National Institutes of Health grant HL083029.

\section{Author details}

'Department of Biochemistry and Cell Biology, MS-140, Rice University, 6100 S Main Street, Houston, TX 77005-1892, USA. ²Department of Biology, MS-3474, Texas A\&M University, College Station, TX 77843-3474, USA. ${ }^{3}$ Department of Biology, Hunter College, 695 Park Avenue, New York, NY 10065, USA.

Received: 5 September 2012 Accepted: 7 December 2012

Published: 17 January 2013 


\section{References}

1. Ley K, Laudanna C, Cybulsky MI, Nourshargh S: Getting to the site of inflammation: the leukocyte adhesion cascade updated. Nat Rev Immunol 2007, 7:678-689.

2. Soehnlein $\mathrm{O}$, Lindbom $\mathrm{L}$, Weber $\mathrm{C}$ : Mechanisms underlying neutrophilmediated monocyte recruitment. Blood 2009, 114:4613-4623.

3. Edwards SW: Biochemistry and Physiology of the Neutrophil. Cambridge, UK: Cambridge University Press; 1994:299.

4. Kuntz RM, Saltzman WM: Neutrophil motility in extracellular matrix gels: mesh size and adhesion affect speed of migration. Biophys 1997, 72:1472-1480

5. Hidalgo A, Peired AJ, Wild MK, Vestweber D, Frenette PS: Complete identification of E-selectin ligands on neutrophils reveals distinct functions of PSGL-1, ESL-1, and CD44. Immunity 2007, 26:477-489.

6. Carlos TM, Harlan JM: Leukocyte-endothelial adhesion molecules. Blood 1994, 84:2068-2101.

7. Albelda SM, Smith CW, Ward PA: Adhesion molecules and inflammatory injury. FASEB J 1994, 8:504-512

8. Dimitroff CJ, Lee JY, Rafii S, Fuhlbrigge RC, Sackstein R: CD44 is a major E-selectin ligand on human hematopoietic progenitor cells. J Cell Biol 2001, 153:1277-1286.

9. Cassatella MA: Neutrophil-derived proteins: selling cytokines by the pound. Adv Immunol 1999, 73:369-509.

10. Montecucco F, Steffens S, Burger F, Da Costa A, Bianchi G, Bertolotto M, Mach F, Dallegri F, Ottonello L: Tumor necrosis factor-alpha (TNF-alpha) induces integrin $\mathrm{CD} 1 \mathrm{~b} / \mathrm{CD} 18$ (Mac-1) up-regulation and migration to the CC chemokine CCL3 (MIP-1alpha) on human neutrophils through defined signalling pathways. Cell Signal 2008, 20:557-568.

11. Nathan CF: Neutrophil activation on biological surfaces. Massive secretion of hydrogen peroxide in response to products of macrophages and lymphocytes. J Clin Invest 1987, 80:1550-1560

12. Weisbart RH, Golde DW, Clark SC, Wong GG, Gasson JC: Human granulocytemacrophage colony-stimulating factor is a neutrophil activator. Nature 1985, 314:361-363.

13. Yong KL, Linch DC: Differential effects of granulocyte- and granulocytemacrophage colony-stimulating factors (G- and GM-CSF) on neutrophil adhesion in vitro and in vivo. Eur J Haematol 1992, 49:251-259.

14. Zimmerman GA, Prescott SM, McIntyre TM: Endothelial cell interactions with granulocytes: tethering and signaling molecules. Immunol Today 1992, 13:93-100.

15. Witko-Sarsat V, Rieu P, Descamps-Latscha B, Lesavre P, Halbwachs-Mecarell L: Neutrophils: molecules, functions and pathophysiological aspects. Lab Invest 2000, 80:617-653.

16. Leonard EJ, Yoshimura T: Neutrophil attractant/activation protein-1 (NAP-1 [interleukin-8]). Am J Res Cell Mol Biol 1990, 2:479-486.

17. Drost EM, MacNee W: Potential role of IL-8, platelet-activating factor and TNF-alpha in the sequestration of neutrophils in the lung: effects on neutrophil deformability, adhesion receptor expression, and chemotaxis. Eur J Immunol 2002, 32:393-403.

18. Frank RS: Time-dependent alterations in the deformability of human neutrophils in response to chemotactic activation. Blood 1990, 76:2606-2612.

19. Norgauer J, Krutmann J, Dobos GJ, Traynor-Kaplan AE, Oades ZG, Schraufstätter IU: Actin polymerization, calcium-transients, and phospholipid metabolism in human neutrophils after stimulation with interleukin-8 and N-formyl peptide. J Invest Derma 1994, 102:310-314.

20. Crossley $\sqcup$ : Neutrophil activation by fMLP regulates FOXO (forkhead) transcription factors by multiple pathways, one of which includes the binding of FOXO to the survival factor Mcl-1. J Leukoc Biol 2003, 74:583-592.

21. Strieter RM, Kasahara K, Allen RM, Standiford TJ, Rolfe MW, Becker FS, Chensue SW, Kunkel SL: Cytokine-induced neutrophil-derived interleukin-8. Am J Pathol 1992, 141:397-407.

22. Hughes SF, Cotter MJ, Evans SA, Jones KP, Adams RA: The role of leukocytes in damage to the vascular endothelium during ischaemia-reperfusion injury. Br J Biomed Sci 2006, 63:166-170.

23. Lee WL, Downey GP: Neutrophil activation and acute lung injury. Curr Opin Crit Care 2001, 7:1-7.

24. Wertheim WA, Kunkel SL, Standiford TJ, Burdick MD, Becker FS, Wilke CA Gilbert AR, Strieter RM: Regulation of neutrophil-derived IL-8: the role of prostaglandin E2, dexamethasone, and IL-4. J Immunol 1993, 151:2166-2175.
25. Tryzmel J, Miskolci V, Castro-Alcaraz S, Vancurova I, Davidson D: Interleukin10 inhibits proinflammatory chemokine release by neutrophils of the newborn without suppression of nuclear factor-kappa B. Pediat Res 2003, 54:382-386.

26. Mulligan MS, Jones ML, Vaporciyan AA, Howard MC, Ward PA: Protective effects of IL-4 and IL-10 against immune complex-induced lung injury. J Immunol 1993, 151:5666-5674.

27. Shanley TP, Vasi N, Denenberg A: Regulation of chemokine expression by IL-10 in lung inflammation. Cytokine 2000, 12:1054-1064.

28. Papayianni A, Serhan CN, Brady HR: Lipoxin A4 and B4 inhibit leukotrienestimulated interactions of human neutrophils and endothelial cells. J Immunol 1996, 156:2264-2272.

29. Serhan CN: Resolution phase of inflammation: novel endogenous antiinflammatory and proresolving lipid mediators and pathways. Ann Rev Immunol 2007, 25:101-137.

30. Serhan CN, Chiang N, Van Dyke TE: Resolving inflammation: dual antiinflammatory and pro-resolution lipid mediators. Nat Rev Immunol 2008 , 8:349-361.

31. Serhan CN, Hong S, Gronert K, Colgan SP, Devchand PR, Mirick G, Moussignac RL: Resolvins: a family of bioactive products of omega-3 fatty acid transformation circuits initiated by aspirin treatment that counter proinflammation signals. J Exp Med 2002, 196:1025-1037.

32. Deban L, Russo RC, Sironi M, Moalli F, Scanziani M, Zambelli V, Cuccovillo I, Bastone A, Gobbi M, Valentino S, Doni A, Garlanda C, Danese S, Salvatori G, Sassano M, Evangelista V, Rossi B, Zenaro E, Constantin G, Laudanna C, Bottazzi B, Mantovani A: Regulation of leukocyte recruitment by the long pentraxin PTX3. Nat Immunol 2010, 11:328-334

33. El Kebir D, Zhang Y, Potempa LA, Wu Y, Fournier A, Filep JG: C-reactive protein-derived peptide 201-206 inhibits neutrophil adhesion to endothelial cells and platelets through CD32. J Leuk Biol 2011, 90:1167-1175

34. Han B, Haitsma JJ, Zhang Y, Bai X, Rubacha M, Keshavjee S, Zhang H, Liu M: Long pentraxin PTX3 deficiency worsens LPS-induced acute lung injury. Int Care Med 2011, 37:334-342.

35. Heuertz RM, Piquette CA, Webster RO: Rabbits with elevated serum Creactive protein exhibit diminished neutrophil infiltration and vascular permeability in C5a-induced alveolitis. Am J Pathol 1993, 142:319-328.

36. Heuertz RM, Tricomi SM, Ezekiel UR, Webster RO: C-reactive protein inhibits chemotactic peptide-induced p38 mitogen-activated protein kinase activity and human neutrophil movement. J Biol Chem 1999, 274:17968-17974.

37. Heuertz RM, Webster RO: Role of C-reactive protein in acute lung injury. Mol Med Today 1997, 3:539-545.

38. Savchenko AS, Inoue A, Ohashi R, Jiang S, Hasegawa G, Tanaka T, Hamakubo T, Kodama T, Aoyagi Y, Ushiki T, Naito M: Long pentraxin 3 (PTX3) expression and release by neutrophils in vitro and in ulcerative colitis. Path Intern 2011, 61:290-297.

39. Baudino L, Nimmerjahn F, Azeredo-da-Silveira S, Martinez-Soria E, Saito T, Carroll M, Ravetch JV, Verbeek JS, Izui S: Differential contribution of three activating lgG Fc receptors (FcgammaRl, FcgammaRIII, and FcgammaRIV) to IgG2a- and lgG2b-induced autoimmune hemolytic anemia in mice. J Immunol 2008, 180:1948-1953.

40. Nimmerjahn F, Ravetch JV: Fcgamma receptors as regulators of immune responses. Nat Rev Immunol 2008, 8:34-47.

41. Goulding NJ, Knight SM, Godolphin JL, Guyre PM: Increase in neutrophil Fc gamma receptor I expression following interferon gamma treatment in rheumatoid arthritis. Ann Rheum Dis 1992, 51:465-468.

42. Nimmerjahn F, Ravetch JV: Analyzing antibody-Fc-receptor interactions. Meth Mol Biol 2008, 415:151-162

43. Tsuboi N, Asano K, Lauterbach M, Mayadas TN: Human neutrophil Fc ${ }^{3}$ receptors initiate and play specialized nonredundant roles in antibodymediated inflammatory diseases. Immunity 2008, 28:833-846.

44. Bharadwaj D, Mold C, Markham E, Du Clos TW: Serum amyloid P component binds to Fcgamma receptors and opsonizes particles for phagocytosis. J Immunol 2001, 166:6735-6741.

45. Mold C, Baca R, Du Clos TW: Serum amyloid P component and C-reactive protein opsonize apoptotic cells for phagocytosis through Fcgamma receptors. J Autoimmun 2002, 19:147-154.

46. Mold C, Gresham HD, Du Clos TW: Serum amyloid P component and Creactive protein mediate phagocytosis through murine Fc gamma Rs. J Immunol 2001, 166:1200-1205. 
47. Moalli F, Jaillon S, Inforzato A, Sironi M, Bottazzi B, Mantovani A, Garlanda C: Pathogen recognition by the long pentraxin PTX3. J Biomed Biotechnol 2011, 2011:830421.

48. Nelson SR, Tennent GA, Sethi D, Gower PE, Ballardie FW, Amatayakul-Chantler S, Pepys MB: Serum amyloid $\mathrm{P}$ component in chronic renal failure and dialysis. Intern J Clin Chem 1991, 200:191-199.

49. Mortensen RF, Beisel K, Zeleznik NJ, Le PT: Acute-phase reactants of mice. II. Strain dependence of serum amyloid P-component (SAP) levels and response to inflammation. J Immunol 1983, 130:885-889.

50. Pilling D, Buckley CD, Salmon M, Gomer $\mathrm{RH}$ : Inhibition of fibrocyte differentiation by serum amyloid P. J Immunol 2003, 171:5537-5546.

51. Crawford JR, Pilling D, Gomer RH: FcgammaRI mediates serum amyloid P inhibition of fibrocyte differentiation. J Leuk Biol 2012, 92:699-711.

52. Pilling D, Roife D, Wang M, Ronkainen SD, Crawford JR, Travis EL, Gomer RH: Reduction of bleomycin-induced pulmonary fibrosis by serum amyloid $\mathrm{P}$. J Immunol 2007, 179:4035-4044.

53. Castaño AP, Lin SL, Surowy T, Nowlin BT, Turlapati SA, Patel T, Singh A, Li S, Lupher ML Jr, Duffield JS: Serum amyloid P inhibits fibrosis through Fc gamma R-dependent monocyte-macrophage regulation in vivo. Sci Transl Med 2009, :5ra13.

54. Pepys MB, Gallimore JR, Lloyd J, Li Z, Graham D, Taylor GW, Ellmerich S, Mangione PP, Tennent GA, Hutchinson WL, Millar DJ, Bennett G, More J, Evans D, Mistry Y, Poole S, Hawkins PN: Isolation and characterization of pharmaceutical grade human pentraxin, serum amyloid $\mathrm{P}$ component and C-reactive protein, for clinical use. J Immunol Meth 2012, 384:92-102.

55. Waddell TK, Fialkow L, Chan CK, Kishimoto TK, Downey GP: Potentiation of the oxidative burst of human neutrophils. A signaling role for L-selectin. J Biol Chem 1994, 269:18485-18491.

56. Polevshchikov AV, Nazarov PG, Kozlov SV, Galkina EV, Berestova LK: The regulation of blood neutrophil functions by C-reactive protein and serum amyloid P. Fiziologicheskii zhurnal imeni IM Sechenova/Rossiiskaia akademiia nauk 1996, 82:67-72.

57. Timoshenko AV, Bovin NV, Shiyan SD, Vakhrushev SY, André S, Gabius HJ: Modification of the functional activity of neutrophils treated with acute phase response proteins. Bioch Biokhimiia 1998, 63:546-550.

58. Galkina EV, Nazarov PG, Polevschikov AV, Berestovaya LK, Galkin VE, Bychkova NV: Interactions of C-reactive protein and serum amyloid $P$ component with interleukin-8 and their role in regulation of neutrophil functions. Russ J Immunol 2000, 5:363-374.

59. Stibenz D, Gräfe M, Debus N, Hasbach M, Bahr I, Graf K, Fleck E, Thanabalasingam $U$, Bührer $C$ : Binding of human serum amyloid $P$ componentto L-selectin. Eur J Immunol 2006, 36:446-456.

60. Shao DD, Suresh R, Vakil V, Gomer RH, Pilling D: Pivotal Advance: Th-1 cytokines inhibit, and Th-2 cytokines promote fibrocyte differentiation. J Leukoc Biol 2008, 83:1323-1333.

61. Fischer $\mathrm{AH}$, Jacobson KA, Rose J, Zeller R: Hematoxylin and eosin staining of tissue and cell sections. Cold Spring Harb Protoc 2008, :prot4986.

62. Maharjan AS, Pilling D, Gomer RH: Toll-like receptor 2 agonists inhibit human fibrocyte differentiation. Fibr Tiss Rep 2010, 3:23.

63. Delaharpe J, Nathan CF: A semi-automated micro-assay for $\mathrm{H} 2 \mathrm{O} 2$ release by human-blood monocytes and mouse peritoneal-macrophages. $J$ Immunol Meth 1985, 78:323-336.

64. Pilling D, Fan T, Huang D, Kaul B, Gomer R: Identification of markers that distinguish monocyte-derived fibrocytes from monocytes, macrophages, and fibroblasts. PLoS One 2009, 4:e7475.

65. Lakatos HF, Burgess HA, Thatcher TH, Redonnet MR, Hernady E, Williams JP, Sime PJ: Oropharyngeal aspiration of a silica suspension produces a superior model of silicosis in the mouse when compared to intratracheal instillation. Exp Lung Res 2006, 32:181-199.

66. Corteling $R$, Wyss $D$, Trifilieff $A$ : In vivo models of lung neutrophil activation. Comparison of mice and hamsters. BMC Pharm 2002, 2:1

67. Sengupta K, Aranda-Espinoza H, Smith L, Janmey P, Hammer D: Spreading of neutrophils: from activation to migration. Biophy J 2006, 91:4638-4648.

68. Kettritz R, Choi M, Rolle S, Wellner M, Luft FC: Integrins and cytokines activate nuclear transcription factor-kappaB in human neutrophils. J Biol Chem 2004, 279:2657-2665.

69. Yong KL, Rowles PM, Patterson KG, Linch DC: Granulocyte-macrophage colony-stimulating factor induces neutrophil adhesion to pulmonary vascular endothelium in vivo: role of beta 2 integrins. Blood 1992, 80:1565-1575.
70. Wittmann S, Rothe G, Schmitz G, Frohlich D: Cytokine upregulation of surface antigens correlates to the priming of the neutrophil oxidative burst response. J Inter Soc Anal Cytol 2004, 57:53-62.

71. Johnson P, Ruffell B: CD44 and its role in inflammation and inflammatory diseases. Inflamm Allergy Drug Targets 2009, 8:208-220.

72. Campanero MR, Pulido R, Alonso IL, Pivel JP, Pimentel-Muiños FX, Fresno M, Sánchez-Madrid F: Down-regulation by tumor necrosis factor-alpha of neutrophil cell surface expression of the sialophorin CD43 and the hyaluronate receptor CD44 through a proteolytic mechanism. Eur J Immunol 1991, 21:3045-3048

73. Dahlgren C, Karlsson A: Respiratory burst in human neutrophils. J Immunol Meth 1999, 232:3-14

74. Quinn MT, DeLeo FR, Bokoch GM: Neutrophil methods and protocols. Methods Mol Biol 2007, 412:7-8

75. Fadok VA, Voelker DR, Campbell PA, Cohen JJ, Bratton DL, Henson PM: Exposure of phosphatidylserine on the surface of apoptotic lymphocytes triggers specific recognition and removal by macrophages. J Immunol 1992, 148:2207-2216

76. In V, Haanen C, Steffens-Nakken H, Reutellingsperger C: A novel assay for apoptosis Flow cytometric detection of phosphatidylserine expression on early apoptotic cells using fluorescein labelled Annexin V. J Immunol Meth 1995, 184:39-51.

77. Derouet M, Thomas L, Cross A, Moots RJ, Edwards SW: Granulocyte macrophage colony-stimulating factor signaling and proteasome inhibition delay neutrophil apoptosis by increasing the stability of Mcl-1. J Biol Chem 2004, 279:26915-26921.

78. Lai L, Alaverdi N, Maltais L, Morse HC 3rd: Mouse cell surface antigens: nomenclature and immunophenotyping. J Immunol 1998, 160:3861-3868.

79. Landsman L, Varol C, Jung S: Distinct differentiation potential of blood monocyte subsets in the lung. J Immunol 2007, 178:2000-2007.

80. Birner $U$, Issekutz TB, Issekutz AC: The role of selectins in VLA-4 and CD18independent neutrophil migration to joints of rats with adjuvant arthritis. Eur J Immunol 1999, 29:1094-1100.

81. Gao JX, Issekutz AC: The beta(1) integrin, very late activation antigen-4 on human neutrophils can contribute to neutrophil migration through connective tissue fibroblast barriers. Immunology 1997, 90:448-454.

82. Lundberg S, Lindholm J, Lindbom L, Hellstrom PM, Werr J: Integrin alpha2beta1 regulates neutrophil recruitment and inflammatory activity in experimental colitis in mice. Inflamm Bowel Dis 2006, 12:172-177.

83. Mambole A, Bigot S, Baruch D, Lesavre P, Halbwachs-Mecarelli L: Human neutrophil integrin alpha9beta1: up-regulation by cell activation and synergy with beta2 integrins during adhesion to endothelium under flow. J Leuk Biol 2010, 88:321-327.

doi:10.1186/1755-1536-6-2

Cite this article as: Maharjan et al:: Serum amyloid P inhibits granulocyte adhesion. Fibrogenesis \& Tissue Repair 2013 6:2.

\section{Submit your next manuscript to BioMed Central and take full advantage of:}

- Convenient online submission

- Thorough peer review

- No space constraints or color figure charges

- Immediate publication on acceptance

- Inclusion in PubMed, CAS, Scopus and Google Scholar

- Research which is freely available for redistribution 